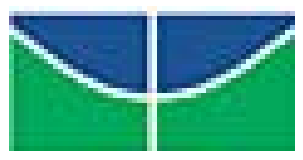

UNIVERSIDADE DE BRASÍLIA - UNB

FACULDADE DE ECONOMIA, ADMINISTRAÇÃO, CONTABILIDADE, CIÊNCIA DA INFORMAÇÃO E DOCUMENTAÇÃO (FACE)

MARIA APARECIDA DE ARAÚJO RAMOS

GESTÃO DA DIVERSIDADE EM UM TRIBUNAL SUPERIOR DO PODER JUDICÁRIO BRASILEIRO: UMA ANÁLISE DA IGUALDADE DE OPORTUNIDADES ENTRE HOMENS E MULHERES NA OCUPAÇÃO DE POSTOS DE COMANDO 


\title{
GESTÃO DA DIVERSIDADE EM UM TRIBUNAL SUPERIOR DO PODER JUDICÁRIO BRASILEIRO: UMA ANÁLISE DA IGUALDADE DE OPORTUNIDADES ENTRE HOMENS E MULHERES NA OCUPAÇÃO DE POSTOS DE COMANDO
}

\begin{abstract}
Monografia apresentada ao Programa de PósGraduação em Administração (PPGA) da Faculdade de Economia, Administração, Contabilidade e Ciência da Informação e Documentação (FACE), da Universidade de Brasília (UnB), como requisito parcial à obtenção do grau de Especialista em Gestão Judiciária.
\end{abstract}

Orientadora: Profa. Dra. Maria de Fátima Bruno - Faria 
Dedico este trabalho aos homens da minha vida, meu querido marido, parceiro e amigo Marcus Aurélio Ramos e nossos amados filhos Marcus Vinícius de Araújo Ramos e Fábio Augusto de Araújo Ramos. 


\section{AGRADECIMENTOS}

Ao Tribunal, órgão que tenho orgulho de pertencer e a quem serei eternamente grata por ter me proporcionado fazer esta Pós - Graduação em Gestão Judiciária.

Aos colegas de trabalho pela dedicação ao responder ao questionário de pesquisa.

A todos os colegas, privilegiados por participar desse inesquecível curso de Especialização em Gestão Judiciária, em especial aos que compuseram, comigo, o divertido grupo de estudo número 5, Ana Lúcia Moraes, Hermínia Lúcia, Edson Santos e Gilberto Ferreira.

Às amigas Vera Lúcia, Déia Barros, Geli, Lucielma, Andréia e Dalila pelas inesquecíveis contribuições.

Aos colegas Wiviane de Sousa Santos, chefe da Seção de Provimento e Vacância do Tribunal e Antônio Serafim de Oliveira por todas as informações prestadas.

À minha admirável amiga, mestra e confidente Dra. Thelma Bernadete de Oliveira, por quem guardo eterna gratidão.

Ao Prof. Dr. Marcus Vinicius Soares Siqueira, pelos ensinamentos e pela competência com que coordenou o curso de Especialização em Gestão Judiciária.

À Profa. Dra. Maria Inez Machado Telles Walter, pela paciência e gentileza em explicar, explicar e explicar os fundamentos da estatística.

Ao Prof. Dr. Eduardo Raupp de Vargas, pela qualidade de seus ensinamentos e pelos exemplos de organização, planejamento e disciplina que demonstrou em sala de aula.

À Profa. Dra. Maria de Fátima Bruno-Faria pela demonstração de competência, dedicação e carinho com que trata os assuntos relacionados à pesquisa. É maravilhoso sentir seu entusiasmo e amor pelo conhecimento. Obrigada pelas inúmeras vezes que procurou fazer-me acreditar que tudo daria certo. 
Sempre que uma mulher faz o melhor que pode, deve fazer duas vezes melhor que o homem para ser considerada apenas $50 \%$ à sua altura. Ainda bem que não é difícil.

Charlotte Whitton 


\section{RESUMO}

As organizações contemporâneas têm vivenciado na atualidade processos de mudança mais dinâmicos e mais freqüentes. Isto por que a força de trabalho apresenta-se cada vez mais heterogênea, em termos de raça, etnia, gênero e outros grupos culturalmente diversos. Esta pesquisa teve por objetivo analisar a percepção dos servidores de um Tribunal do Poder Judiciário brasileiro com relação à igualdade de oportunidade entre homens e mulheres na ocupação de postos de comando. Para tanto foram realizadas pesquisas de campo e documental entre os meses de outubro e dezembro de 2008 nas dependências do Órgão estudado, bem como levantamento de dados nos principais órgãos do Poder Judiciário brasileiro, com relação ao quantitativo de homens e mulheres ocupantes de cargos e funções comissionadas. Adotou-se a Escala de Percepção de Igualdade de Oportunidades entre Mulheres e Homens, desenvolvida e validada por Zauli-Fellows (2006), composta de 34 itens, que representavam quatro fatores (Fator 1, Fator 2, Fator 3 e Fator 4) a serem respondidos em uma escala de resposta Likert e itens sobre dados demográficos. Os questionários foram distribuídos pela pesquisadora para 400 servidores, dos quais 282 foram respondidos. As médias e desvios padrão dos fatores revelaram que as oportunidades para os homens e as mulheres de ocupar cargos e funções comissionadas são muito próximas, não somente no Tribunal estudado, mas nos principais órgãos do Poder Judiciário brasileiro.

Palavras-chave: diversidade, gênero, igualdade, ascensão na carreira. 


\section{LISTA DE GRÁFICOS}

Gráfico 1 - Mulheres predominam entre os que procuram trabalho.................................... 24

Gráfico 2 - Mulheres com nível superior recebem $60 \%$ do rendimento dos homens............. 24

Gráfico 3 - Percentual de ocupação dos cargos comissionados por homens e mulheres........ 44

Gráfico 4 - Percentual de ocupação das funções comissionadas por homens e mulheres...... 45

Gráfico 5 - Percentual de ocupação dos cargos e funções comissionadas no STF em 2008.. 47

Gráfico 6 - Percentual de ocupação dos cargos e funções comissionadas no STJ em 2008.. 47

Gráfico 7 - Percentual de ocupação dos cargos e funções comissionadas no TSE em 2008.. 47

Gráfico 8 - Percentual de ocupação dos cargos e funções comissionadas no TRF em 2008.. 48

Gráfico 9 - Percentual de ocupação dos cargos e funções comissionadas no TRT em 2008.. 48

Gráfico 10 - Percentual de ocupação dos cargos e funções comissionadas no TJDFT em

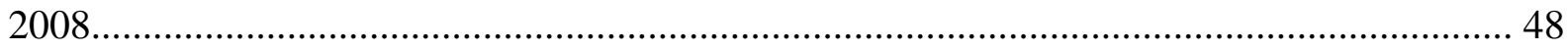

Gráfico 11 - Percentual de ocupação dos cargos e funções comissionadas no CJF em 2008

Gráfico 12 - Percentual de ocupação dos cargos e funções comissionadas no TST em 2008 49

\section{LISTA DE QUADROS}

Quadro 1 - Itens que compõem a Escala de Percepção de Igualdade de Oportunidades entre Mulheres e Homens. 34 


\section{LISTA DE TABELAS}

Tabela 1 - Distribuição da PEA, segundo sexo e escolaridade - Brasil................................ 19

Tabela 2 - Taxa de Atividade, segundo sexo e escolaridade................................................. 19

Tabela 3 - Participação feminina em ocupação de nível superior Brasil 1995 - 2005........... 20

Tabela 4 - Distribuição dos ocupados, segundo sexo e setores de atividade........................... 22

Tabela 5 - Percentagem de participação das ocupações precárias femininas......................... 22

Tabela 6 - Número de Ministros e Ministras no Poder Judiciário 2007................................ 25

Tabela 7- Mulheres em Instâncias de Poder Legislativo 2007............................................... 26

Tabela 8 - Mulheres em Instâncias de Poder Executivo 2007............................................... 26

Tabela 9 - Quantitativo de pessoal que compõe o quadro do órgão estudado........................ 33

Tabela 10 - Ordem decrescente de médias e desvios calculados por fator............................ 38

Tabela 11 - Valores das médias e desvios padrão calculados por item que compõem

o Fator 2 .......

Tabela 12 - Valores das médias e desvios padrão calculados por item que compõem

o Fator 3

Tabela 13 - Valores das médias e desvios padrão calculados por item que compõem

o Fator 1

Tabela 14 - Valores das médias e desvios padrão calculados por item que compõem

o Fator 4

Tabela 15 - Séries históricas de quantitativo e de percentual de ocupação de cargos comissionados por homens e mulheres no órgão estudado

Tabela 16 -Séries históricas de quantitativos e de percentual de ocupação de funções comissionadas por homens e mulheres no órgão estudado

Tabela 17 - Quantitativo de cargos e funções comissionadas e percentual de ocupação por servidores homens e mulheres em importantes órgãos do Poder Judiciário 


\section{SUMÁRIO}

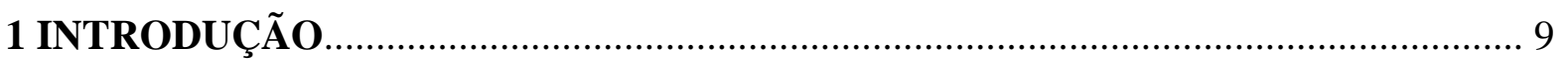

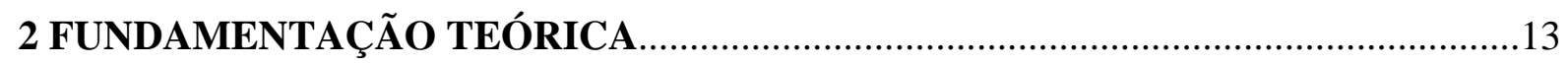

2.1 A mulher na sociedade ao longo do tempo..................................................................... 13

2.2 Participação da mulher no mercado de trabalho................................................................ 18

2.3 A mulher no contexto organizacional: gestão da diversidade.............................................. 27

2.4 Análise de pesquisas científicas sobre gênero e trabalho..................................................... 29

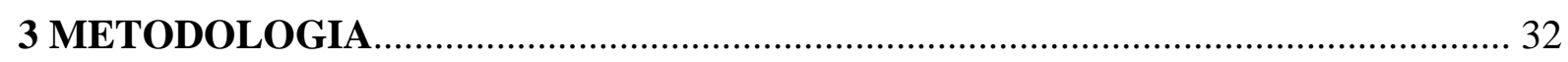

3.1 Caracterização da pesquisa...................................................................................... 32

3.2 Caracterização da organização estudada........................................................................... 32

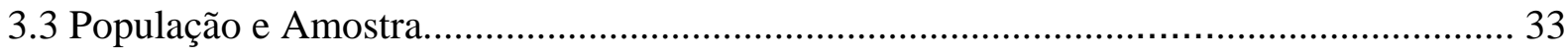

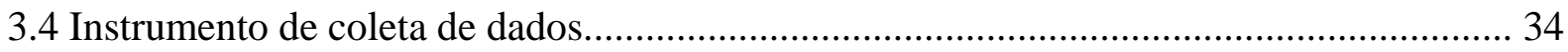

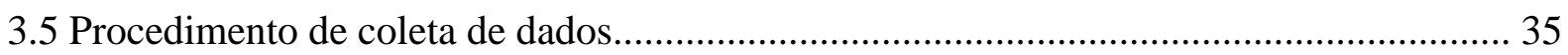

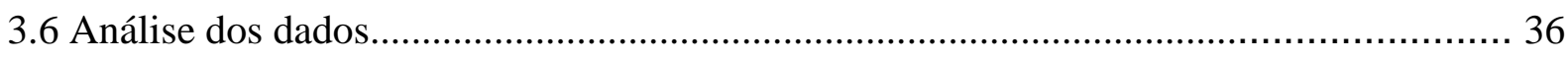

4 APRESENTAÇÃO E DISCUSSÃO DOS RESULTADOS............................................. 37

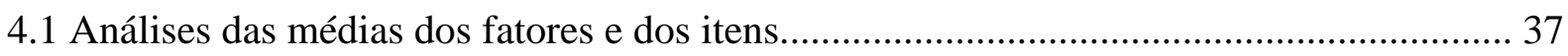

4.2 Análise das médias dos itens que compõem os fatores.................................................... 38

4.3 Análise das correlações entre os fatores e as variáveis independentes............................... 42

4.4 Apresentação e análise dos resultados da pesquisa no Sistema de Administração de Recursos Humanos do órgão estudado............................................................................. 43

4.5 Apresentação e análise dos resultados da pesquisa nos principais órgãos do Poder Judiciário brasileiro.......................................................................................................... 46

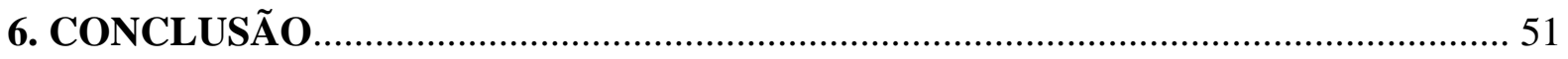

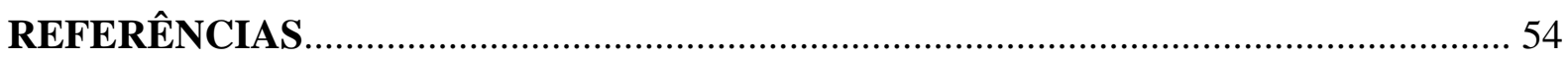

ANEXO A - Questionário Aplicado à Amostra da Organização Estudada: Escala de Percepção de Igualdade de Oportunidades entre Mulheres e Homens...................................... 58

APÊNDICE A - Planilha de coleta de dados enviada aos principais órgãos do Poder Judiciário. 65 


\section{INTRODUÇÃO}

O estudo das questões relacionadas às mulheres tem ganhado considerável espaço na literatura e no meio acadêmico.

O crescente interesse pelo tema está associado a diversos fatores, entre eles os sociais, como as mudanças de hábitos culturais nas sociedades ocidentais ocorridas a partir de meados do século XX, com uma maior abertura para as mulheres questionarem os papéis que lhes eram impostos pelos padrões socioculturais vigentes até então. Talvez a mudança cultural mais marcante tenha sido o questionamento do papel da mulher como esposa e dona de casa, tendo como tarefas exclusivas o cuidado da casa, filhos e marido. A partir do momento em que esse papel foi colocado em xeque, abriu-se um horizonte mais amplo de oportunidades para elas. A conquista de direitos legais, inserção no espaço público, notadamente no mundo do trabalho remunerado, importantes alterações na esfera privada e o enfraquecimento da hierarquia de gênero nas relações conjugais, são exemplos dessa amplitude. (BRUSCHINI, 2007).

A entrada e permanência das mulheres no mercado de trabalho são processos inseridos em distintos contextos e que têm distintas motivações. Podem-se colocar em destaque dois conjuntos de motivações: o primeiro relacionado à realização individual, o desejo de autonomia e de independência, ligados aos valores modernos resultantes tanto das lutas feministas por direitos iguais, quanto do processo de individualização da sociedade contemporânea; o segundo refere-se à necessidade econômica, para a complementação da renda familiar, especialmente em sociedade tão desigual quanto a brasileira.

Segundo Picanço (2005) as pesquisas sobre gênero e trabalho orientaram-se desde cedo na direção da mensuração da desigualdade da estrutura ocupacional, através das séries temporais construídas com base nas análises de dados da Pesquisa Nacional por Amostra de Domicílio do Instituto de Geografia e Estatística (PNAD/IBGE), Pesquisa de Emprego e Desemprego do Departamento Intersindical de Estatística e Estudos Socioeconômicos (PED/DIEESE), Censos, bem como nas investigações que utilizam metodologias qualitativas sobre empresas, ramos de atividade, ocupações específicas etc.

Recente pesquisa realizada pelo Instituto de Brasileiro de Geografia e Estatística (IBGE) apresentou resultados que enfatizam aspectos importantes quanto ao mercado profissional da mulher e que dão mostras desta realidade, conforme se verifica a seguir: 
Para as mulheres que possuem nível superior completo, o rendimento médio habitual foi de R\$ 2.291,80 em janeiro de 2008; enquanto que para os homens esse valor foi de $\mathrm{R} \$ 3.841,40$. Ainda que comparando trabalhadores que possuem o nível superior, o rendimento das mulheres é cerca de $60 \%$ do rendimento dos homens, indicando que mesmo com grau de escolaridade mais elevado as discrepâncias salariais entre homens e mulheres não diminuem. (IBGE, 2008).

Outros aspectos que merecem destaque são as desigualdades entre homens e mulheres quanto à inserção no mercado de trabalho e a maior vulnerabilidade dessas no que tange aos impactos sociais. Por exemplo, em caso de necessidade de demissão, sabidamente, as mulheres são as primeiras a serem dispensadas, em vista de suas características peculiares, como gravidez, licença maternidade. As dificuldades de obtenção de emprego são maiores para as mulheres, tanto que suas taxas de desemprego são sistematicamente superiores às masculinas. Entretanto, ao analisar o comportamento do mercado de trabalho brasileiro nos últimos anos, chamam a atenção a intensidade e a constância do crescimento da força de trabalho feminino, como afirmam Barros et al. (1999 apud MOURÃO, 2006).

\begin{abstract}
A participação feminina no mercado de trabalho tem aumentado de forma linear e praticamente alheia às flutuações da atividade econômica. Seja em fases de recessão, seja nos ciclos de expansão da economia, a taxa de atividade das mulheres, em particular dos cônjuges com filhos, tem crescido no Brasil nos últimos 20 anos. A absorção de mão-de-obra feminina tem sido superior à masculina em todas as fases recentes da economia brasileira, sendo que a participação das mulheres tem aumentado em cerca de 15\% por década (BARROS et al., 1999 apud MOURÃO, 2006, p.17).
\end{abstract}

Esta não é uma característica exclusiva do mercado de trabalho das brasileiras. Estudo recente sobre o mercado de trabalho na Europa contemporânea trouxe à tona uma realidade muito próxima à evidenciada pelas trabalhadoras brasileiras, conforme trecho a seguir:

O crescimento espetacular da atividade feminina, que remonta ao início dos anos 1960, é uma onda súbita que ninguém tinha previsto na época e que nada deteve desde então, nem a falta de emprego, nem a queda do crescimento, nem a escalada de um desemprego em massa e estrutural. Uma onda súbita que, em graus diversos, atingiu toda a Europa. (MARUANI, 2008, p. 36).

Maruani (2008) destaca, ainda, alguns dados que demonstram as semelhanças das desigualdades entre os assalariados homens e mulheres na Europa, levantados por órgãos oficiais europeus, conforme trecho a seguir: 
Os últimos dados de que dispomos no âmbito europeu revelam que as diferenças de salário, em 2001, oscilam entre 6\% e 21\%, com base nas cifras do European Community Household Panel, e entre 11 e 30\%, segundo dados do European Structure of Earning Survey (Meuders, Plasman e Rycx, 2005). (MARUANI, 2008, p. 43).

Segundo Lallement (2008), no Japão as mulheres são relegadas à precariedade, aos baixos salários e à invisibilidade (estão fora do organograma da empresa) enquanto que nada menos que $40 \%$ dos homens japoneses se beneficiam do emprego vitalício e de altos salários.

Ressalta ainda, que [...] "a empresa francesa é tão discriminante, ou até mais, que seu alter ego japonês: a política de recrutamento é mais desfavorável, para estatutos iguais, às mulheres, e as novas técnicas de produção beneficiam mais os homens”. (LALLEMENT, 2008, p. 57).

Informações que demonstram que apesar do considerável avanço, o mercado de trabalho feminino mundial ainda está em construção; por isso, estudos que reúnam aspectos teóricos e pesquisas empíricas enriquecem o conhecimento sobre o tema e auxiliam na discussão sobre a inserção feminina em mercados formais de trabalho - até então dominado por homens.

Investigar o desenvolvimento profissional da mulher e sua percepção sobre as oportunidades de crescimento contribuirá para um maior conhecimento sobre a atividade feminina e permitirá, dentre outros, rever os modelos de Gestão de Pessoas nesse processo.

Por todo o exposto, e considerando não haver registro de estudos que tenham investigado a questão da igualdade de oportunidades entre homens e mulheres, especificamente no Poder Judiciário; que a sobrevivência das instituições, inclusive a públicas, está condicionada à qualidade da gestão de pessoas; que atrair manter e gerir talentos é um desafio em qualquer organização; que as mulheres representam percentual cada vez maior na força de trabalho, inclusive no judiciário, todos esses aspectos constituíram fortes argumentos na decisão de realizar este estudo. Ademais, o tema está em consonância com percepções de importantes estudiosos do assunto, conforme trechos de conclusões de trabalhos a seguir:

[...] as trabalhadoras brasileiras obtiveram algum progresso no mercado de trabalho, embora tenham persistido inúmeras condições desfavoráveis [...] a persistência de traços de desigualdade revela-se igualmente em outras dimensões: na esfera ocupacional, em cursos e profissões em segmentos culturais, sociais e de humanidades, nas desigualdades salariais. (BRUSCHINI, 2008, p. 31).

O fato de as mulheres constituírem agora quase metade da força de trabalho é uma mudança muito importante. Ainda assim, a questão das desigualdades de sexo, de 
suas novas roupagens e de seus velhos resquícios permanece. [...] as mulheres, quase tão numerosas quanto os homens na esfera do trabalho produtivo, estão sempre atoladas em um pântano de desigualdades estagnantes e rebeldes. (MARUANI, 2008, p. 50).

A segregação setorial e ocupacional por gênero é um fenômeno que está na essência das desigualdades de gênero no mercado de trabalho. Diante da crescente inserção das mulheres nas atividades extra-domésticas e de seu maior nível de escolaridade em relação ao homem (uma característica de praticamente todas as sociedades industrializadas do Ocidente), as diferenças relacionadas às condições de trabalho e aos salários concentram-se cada vez mais na segregação setorial e ocupacional. (SALAS; LEITE, 2008, p. 103)

O objetivo geral desse estudo foi investigar qual é a percepção dos servidores de um órgão do Poder Judiciário brasileiro, com relação à igualdade de oportunidades entre homens e mulheres na ocupação de postos de comando.

O trabalho foi dividido em cinco capítulos, com o propósito de melhor organizar a apresentação dos achados na literatura revisada e nas pesquisas documental e de campo empreendidas.

O capítulo 1 introduz o tema e apresenta questões que envolvem a mulher e o mercado de trabalho; no capítulo 2 e respectivas seções foram apresentados históricos da participação da mulher na sociedade, no mercado de trabalho e sua evolução no contexto organizacional; o capítulo 3 foi dedicado ao detalhamento da metodologia adotada no levantamento e no tratamento dos dados utilizados na realização do trabalho, no $4^{\circ}$ foram apresentados e discutidos os resultados da pesquisa e finalmente, no $5^{\circ}$ e último capítulo são descritas as conclusões e apresentadas sugestões para estudos futuros. 


\section{FUNDAMENTAÇÃO TEÓRICA}

Este capítulo foi organizado em três seções que buscam, por meio de estudo da evolução histórica da mulher, das transformações do mercado de trabalho feminino e da diversidade organizacional, compreender o atual panorama dos servidores de um órgão público federal, com relação à igualdade de oportunidades entre homens e mulheres na ocupação de postos de comando.

\subsection{A mulher na sociedade ao longo do tempo}

Para iniciar a base teórica do presente estudo, torna-se imprescindível tratar da evolução histórica da mulher na sociedade, que se inicia desde os primórdios até alcançar o mundo contemporâneo.

A supremacia masculina é registrada desde o início do mundo. Embora sem o arcabouço científico, a igreja católica pregou, desde sempre, que Deus criou Adão e a partir deste, criou Eva. Dessa seqüência de eventos, tirou-se a conclusão ‘definitiva’ sobre a posição subalterna da mulher na sociedade, cuja submissão faria parte do 'plano divino'. A mulher desde sempre foi identificada como um ser minoritário e incapaz, ora tratada com desprezo, ora com insignificância. A mulher não era considerada como indivíduo social, imbuída de cidadania, mas tida apenas como progenitora e responsável por criar os filhos e manter a limpeza da casa. A filha recebia a educação e orientação dada pela mãe com o objetivo de se casar e isto ocorria com as novas gerações de filhas, numa seqüência ideológica passada de geração em geração. (BEAUVOIR, 1980; PRIORE, 2000).

No Brasil, em meados do século XIX, a estrutura doméstica do lar demandava mais e mais a presença da mulher exclusivamente no espaço privado, conforme destacado por Priore (2000) a seguir:

\footnotetext{
O desenvolvimento das cidades e da vida urbana no século XIX influi na disposição do espaço no interior da residência, tornando-a mais aconchegante; deixou ainda mais claros os limites do convívio e as distâncias sociais entre a nova classe e o povo, permitindo um processo de privatização da família marcado pela valoração da intimidade. (PRIORE, 2000, p. 228).
} 
A mulher ficava, assim, restrita aos afazeres de mãe e dona-de-casa. Outras ocupações eram relacionadas à costura e pequeno comércio de doces, desde que ela não se expusesse ao público. Era ela quem garantia a estabilidade do casal e da família, conforme exposto a seguir:

\begin{abstract}
Convém não esquecer que a emergência da família burguesa ao reforçar no imaginário a importância do amor familiar e do cuidado com o marido e com os filhos, redefine o papel feminino e ao mesmo tempo reserva para a mulher novas e absorventes atividades no interior do espaço doméstico. Percebe-se o endosso desse papel por parte dos meios médicos, educativos e da imprensa na formulação de uma série de propostas que visavam 'educar' a mulher para o seu papel de guardiã do lar e da família - a medicina por exemplo, combatia severamente o ócio e sugeria que as mulheres se ocupassem ao máximo dos afazeres domésticos. (PRIORE, 2000, p.230).
\end{abstract}

Contudo, essa posição “marginalizada” da mulher começou a mudar de forma. Com o advento da modernidade e da revolução industrial, as famílias se viram forçadas a economizar e a mulher obrigada a cooperar com o sustento da casa. No entanto, essa cooperação não foi fácil. A sociedade da época não aceitava o fato de a mulher querer trabalhar. Quando isso ocorria, o marido era mal visto, uma vez que o sustento da casa era sua obrigação. E o fato de a mulher ter que trabalhar transmitia à sociedade a percepção de que o marido era um pobre fracassado. Portanto, a busca pela igualdade de direitos não surgiu repentinamente. Esse movimento é resultado das mudanças sociais e econômicas de uma época e principalmente de uma procura lenta, porém constante, da mulher, como ressaltado na seguinte passagem:

\begin{abstract}
As mulheres de classe mais abastadas não tinham muitas atividades fora do lar. Eram treinadas para desempenhar o papel de mãe e as chamadas "prendas domésticas” - orientar os filhos, fazer ou mandar fazer a cozinha, costurar e bordar. Outras menos afortunadas viúvas ou de uma elite empobrecida, faziam doces por encomenda, arranjos de flores, bordados a crivo, davam aulas de piano e solfejo, e assim puderam ajudar no sustento e na educação da numerosa prole. Entretanto, essas atividades, além de não serem muito valorizadas, não eram bem-vistas socialmente. Tornavam-se facilmente alvo de maledicência por parte de homens e mulheres que acusavam a incapacidade do homem na casa, ou observavam sua decadência econômica. Por isso, muitas vendiam o produto de suas atividades através de outras pessoas por não querer aparecer. Na época, era voz comum que a mulher não precisava, e não deveria ganhar dinheiro. (PRIORE, 2000, p.249).
\end{abstract}

Até no Código Civil de 1916, ela era considerada incapaz, com o mesmo estatuto dos indígenas e das crianças, como rezava o artigo 242. (BRASIL, 1916).

Art. 242 - A mulher não pode, sem o consentimento do marido:

I. Praticar atos que este não poderia sem o consentimento da mulher.

II. Alienar, ou gravar de ônus real, os imóveis do seu domínio particular, qualquer que seja o regime dos bens. 
III. Alienar os seus direitos reais sobre imóveis de outrem.

IV. Aceitar ou repudiar herança ou legado.

V. Aceitar tutela, curatela ou outro múnus públicos.

VI. Litigar em juízo civil ou comercial, a não ser nos casos indicados nos arts. 248 e 251.

VII. Exercer profissão.

VIII. Contrair obrigações, que possam importar em alheação de bens do casal.

IX. Aceitar mandato.

O artigo 380 do mesmo código dava ao homem o exercício do pátrio poder permitindo tal exercício à mulher apenas na falta ou impedimento do marido. O diploma do artigo 385 dá ao pai a administração dos bens do filho e à mãe, somente na falta do cônjuge varão. (BRASIL, 1916).

Com o Código Eleitoral de 1932 surgiu um avanço nos direitos da mulher quando o referido código permitiu à mulher o exercício do voto aos vinte e um anos de idade, tendo a Constituição Federal de 1934 reduzido essa idade para dezoito anos. (BRASIL, 1993).

Trinta anos após, com o advento da Lei $\mathrm{n}^{\circ}$ 4.121/62 (Estatuto da Mulher Casada) o Código Civil sofreu significativas mudanças. O artigo 393 que retirava da mulher o pátrio poder, em relação aos filhos do casamento anterior, quando contraísse novas núpcias, teve sua redação alterada proclamando que a mulher não mais perderia os direitos do pátrio poder se contraísse novas núpcias. (BRASIL, 1962).

O artigo 380 concedeu o exercício do pátrio poder a ambos os pais e a mulher casada passou a ter os mesmos direitos que o marido, e somente não poderia praticar sozinha aqueles atos que o cônjuge estava impedido de realizar sem a assistência da mulher. A lei do divórcio (BRASIL, 1977), estabelece a reciprocidade de prestação alimentar, vinculando o pagamento dos alimentos ao binômio necessidade-possibilidade. O Estatuto da Criança e do Adolescente consagrou, definitivamente, o princípio constitucional da igualdade estabelecendo que o pátrio poder será exercido "em igualdade de condições pelo pai e pela mãe" e que o dever de sustento, guarda e educação dos filhos cabe a ambos. (BRASIL, 1990).

Para a Igreja católica, foi por meio de Eva - que tem um equivalente mitológico em Pandora e sua caixa de desgraças - que o pecado entrou no mundo. Os padres, no confessionário, vigiavam de perto "gestos, atos, sentimentos e até sonhos”, como afirma Priore (2000). Vigiava-se também qualquer sinal de heresia ou de bruxaria. 
Num cenário em que doença e culpa se misturavam, o corpo feminino era visto, tanto por pregadores da Igreja católica quanto por médicos, como um palco nebuloso e obscuro no qual Deus e o Diabo se digladiavam. Qualquer doença, qualquer mazela que atacasse a mulher era interpretada como um indício da ira celestial contra pecados cometidos, ou então era diagnosticada como sinal demoníaco ou feitiço diabólico. (PRIORE, 2000, p. 78).

Para Priore (2000) o que propiciou a conquista de trabalho diferenciado para a mulher, além das mudanças sociais, foi o acesso à escrita, aos estudos. Iniciando-se nas primeiras letras em casa, liam romances e escreviam cadernos de receitas, cartas, diários, textos confessionais. Umas iam para internatos de freiras, outras para as primeiras escolas públicas ou grupos escolares. A profissionalização se dava no âmbito do cuidado feminino a crianças e adolescentes: tornavam-se professoras ou enfermeiras. As mais pobres eram empregadas domésticas ou trabalhavam nas fábricas de tecido.

De acordo com Priore (2000) as primeiras e notáveis mulheres instruídas foram, no Brasil: Amélia de Freitas, primeira brasileira a concorrer a uma cadeira na Academia Brasileira de Letras e redatora de uma revista literária no Recife, coincidentemente casada com o jurista Clovis Bevilacqua, autor do Código Civil de 1916; a professora e escritora Firmina dos Reis; Nísia Floresta Brasileira, considerada a precursora das idéias de igualdade e independência da mulher; Luisa Amélia de Queiroz Brandão, poetisa piauiense; Cora Coralina, a escritora e doceira goiana; e a libertária Maria Lacerda de Moura. Mas a maioria ainda alcançava alguma ascensão social pelo casamento:

\footnotetext{
Uma imensa população composta por familiares consangüíneos, tios, sobrinhos e agregados compunha a 'família de elite'. "No interior desta, a mulher ficava restrita à esfera do espaço privado e muitas delas nasceram, cresceram e morreram sem jamais ter saído de uma fazenda de gado” [...] Como mulher-esposa, seu valor perante a sociedade estava diretamente ligado à 'honestidade' expressa pelo seu recato, pelo exercício de suas funções dentro do lar e pelos inúmeros filhos que daria ao marido. (PRIORE, 2000, p. 265).
}

O movimento influenciado por publicações como "O Segundo Sexo" (lançado em 1949) de Simone de Beauvoir - escritora, filósofa existencialista e feminista francesa - passa a defender que a hierarquia entre os sexos não é uma fatalidade biológica e sim uma construção social, mantida pelas próprias mulheres sobre suas filhas. Para Beauvoir (1980), o complexo de inferioridade e o conformismo são desenvolvidos nas mulheres desde a infância. Pela monotonia das tarefas domésticas, pela exaustão da dupla jornada, pelo fraco conhecimento do mundo e até pela menor massa muscular e fisiologia nervosa instável, que limitavam nelas o aventurar-se, escalar picos, pilotar aviões, correr riscos. 
A hierarquia dos sexos manifesta-se a ela primeiramente na experiência familiar; compreende pouco a pouco que, se a autoridade do pai não é a que se faz sentir mais quotidianamente, é, entretanto, a soberana; reveste-se ainda de mais brilho pelo fato de não ser vulgarizada [...] A vida do pai é cercada de um prestígio misterioso: as horas em que trabalha, os objetos que o cercam, suas ocupações e manias têm um caráter sagrado. Ele é quem alimenta a família, é o responsável e o chefe. Habitualmente trabalha fora e é através dele que a casa se comunica com o resto do mundo: ele é a encarnação desse mundo aventuroso, imenso, difícil, maravilhoso; ele é a transcendência, ele é Deus. (BEAUVOIR, 1980, p. 28).

Assim, a mulher fica sabendo, desde cedo, 'quem manda': o pai e, mais tarde, o marido. Sua vida é limitada aos afazeres domésticos, e se alguma coisa ela deve aprender, essa 'coisa' também deve ter ligação com o lar: cozinhar, costurar, fazer doces. A ela devem bastar a atenção e cuidado ao 'repouso do guerreiro', de modo que ele não seja perturbado pelas crianças. As refeições devem alimentá-lo bem para o trabalho e seu repouso é sagrado, não podendo ser incomodado com barulhos ou queixas. A dinâmica da casa deve assegurar ao chefe de família o conforto do chinelo, do banho preparado com antecedência, da roupa lavada e passada, enfim, de todas as regalias devidas ao dono da casa e senhor dos filhos e da esposa.

[...] Se a menina lê os jornais, se ouve a conversa dos adultos, constata que hoje, como outrora, os homens dirigem o mundo. Os chefes de Estado, os generais, os exploradores, os músicos, os pintores que ela admira são homens; são homens que fazem seu coração bater de entusiasmo. (BEAUVOIR, 1980, p. 31).

Suas leituras devem restringir-se à ‘série rosa’ e aos ‘cadernos femininos’, não a livros nem jornais, que fazem parte do universo masculino. Dessa forma, alheada do mundo, ela acaba por conformar-se com sua 'sina' de iletrada, não lhe cabendo opinar sobre assuntos alheios ao lar, às crianças, à cozinha. Mesmo freqüentando escolas, a ela cabe desempenhar as funções domésticas, à custa de cansaço, sono, desânimo. A literatura é abundante na exaltação do 'amor materno', cantado em prosa e verso, para confirmar e consolidar sua 'vocação exclusiva’ para as lides domésticas. Os heróis de seus sonhos são os homens: aventureiros, cheios de iniciativa, proprietários de terras, abastados e capazes de ter e bancar uma vida própria e próspera.

[...] a partir da puberdade, a jovem perde terreno nos domínios intelectuais e artísticos. Há muitas razões para isso. Uma das mais freqüentes está em que a adolescente não encontra em volta de si os incentivos que oferecem a seus irmãos; ao contrário: querem que ela seja também uma mulher e é-lhe preciso acumular as tarefas de seu trabalho profissional com as que a feminilidade implica. [...] Os trabalhos caseiros ou as tarefas mundanas que a mãe não 
hesita em impor à estudante, à aprendiz, acabam de exauri-la [...] A mãe mostra-se surdamente hostil à libertação da filha, e mais ou menos deliberadamente esforça-se por freá-la. Da moça exigem que fique em casa, fiscalizam-lhe as saídas: não a encorajam em absoluto a escolher seus divertimentos, seus prazeres. É raro ver mulheres organizarem sozinhas uma longa viagem, a pé ou de bicicleta, ou dedicar-se a um jogo como o de bilhar, de bolas etc. (BEAUVOIR, 1980, p. 71-72).

O conformismo se instala assim como a crença em sua própria inferioridade. Isso até os anos 60, quando eclodiu o movimento hippie nos Estados Unidos e em Paris o movimento estudantil, que mudaram os costumes e liberaram os corpos para o amor livre e a vida sem amarras. Muita água rolou, mas, a partir de então, o véu da tutela patriarcal se esgarçara irreversivelmente. Claro que nem todas as mulheres ousaram ou puderam libertar-se e ainda é grande o estado de servidão ou escravidão da mulher pobre no mundo todo. Mas uma nova posição social da mulher foi buscada em massa. Buscada onde? Nas escolas, nas universidades, no direito de ir e vir. (BEAUVOIR, 1980; PRIORE, 2000).

Inspirado em Beauvoir e soprado pelos ventos da liberação, o movimento feminino está intrinsecamente relacionado à luta pela igualdade de direitos em todos os campos, muito bem lembrada e registrada pela Organização das Nações Unidas (ONU) a qual expõe os direitos da mulher, que são - nada mais nada menos - que 'direitos humanos’:

\begin{abstract}
Direito à vida; Direito à liberdade e a segurança pessoal; Direito à igualdade e a estar livre de todas as formas de discriminação; Direito à liberdade de pensamento; Direito à informação e à educação; Direito à privacidade; Direito à saúde e a proteção desta; Direito a construir relacionamento conjugal e a planejar sua família; Direito a decidir ter ou não ter filhos e quando tê-los; Direito aos benefícios do progresso científico; Direito à liberdade de reunião e participação política; Direito a não ser submetida a torturas e maltrato. (IPAS, 2007).
\end{abstract}

2.2 Participação da mulher no mercado de trabalho

As estatísticas oficiais, as Pesquisas Nacionais por Amostra de Domicílios (Pnads), Relação Anual de Informações Sociais do Ministério do Trabalho (Anuário Rais), destacam algumas das principais tendências da inserção laboral das brasileiras, marcadas por progressos e atrasos: de um lado a intensidade e a constância do aumento da participação feminina no mercado de trabalho, de outro, o elevado desemprego das mulheres e a má qualidade do emprego feminino; de um lado, a conquista de bons postos e o acesso a carreiras e profissões de prestígio por parte de mulheres escolarizadas, de outro, o predomínio do trabalho em atividades precárias e informais. 
De acordo com estudo realizado por Bruschini, Ricoldi e Mercado (2008), os indicadores mostram que a população economicamente ativa (PEA) feminina aumentou consideravelmente no período de 1995 - 2005, assim como as taxas de atividade e os percentuais femininos no conjunto dos trabalhadores, motivo pelo qual referido estudo foi objeto de análise neste trabalho, conforme detalhado nas tabelas apresentadas ao longo desta seção.

Segundo Bruschini, Ricoldi e Mercado (2008), a expansão da escolaridade, a que as brasileiras têm cada vez mais acesso, é um dos fatores de maior impacto sobre o ingresso das mulheres no mercado de trabalho.

Os primeiros dados objeto de estudo por Bruschini, Ricoldi e Mercado (2008), foi com relação à distribuição da População Economicamente Ativa (PEA), considerando sexo e escolaridade, conforme detalhado na tabela a seguir:

Tabela 1 - Distribuição da PEA, segundo sexo e escolaridade - Brasil

\begin{tabular}{l|c|c|c|c}
\hline \multirow{2}{*}{ Anos de estudo } & \multicolumn{2}{|c|}{1995} & \multicolumn{2}{c}{2005} \\
\cline { 2 - 5 } & Homens & Mulheres & Homens & Mulheres \\
\hline $\begin{array}{l}\text { Sem instrução e } \\
\text { menos de 1 ano }\end{array}$ & 16,3 & 13,2 & 10,1 & 7,6 \\
\hline 1 a 3 anos & 19 & 16,5 & 12,5 & 9,4 \\
\hline 4 a 7 anos & 34,1 & 31,9 & 28,6 & 24,3 \\
\hline 8 a 10 anos & 13,4 & 13,6 & 17,6 & 17,1 \\
\hline 11 a 14 anos & 12,2 & 18,1 & 24,6 & 31,7 \\
\hline 15 ou mais & 4,8 & 6,5 & 6,2 & 9,5 \\
\hline Total (\%) & 100 & 100 & 100 & 100 \\
\hline Milhões & 44,2 & 30 & 54.290 .827 & 41.741 .144 \\
\hline
\end{tabular}

Fonte: IBGE/Pnads:micro dados do período de 1995 - 2005.

Adaptado de: Bruschini; Ricoldi e Mercado (2008, p. 21).

Da análise dos dados verifica-se que 38\% das trabalhadoras possuíam mais oito anos de estudo em 1995 e em 2005 este percentual passou para 58\%. Com relação aos homens o percentual foi 30,4\% em 1995 e 48\% em 2005.

Outro aspecto destacado no estudo foi com relação ao impacto da escolaridade na taxa de atividade, conforme pode ser observado abaixo:

Tabela 2 - Taxa de Atividade, segundo sexo e escolaridade

\begin{tabular}{l|r|r} 
& \multicolumn{2}{|c}{ (Brasil - 2005) } \\
\hline Escolaridade & Homens & Mulheres \\
\hline $\begin{array}{l}\text { Sem instrução e } \\
\text { menos de 1 ano }\end{array}$ & 68,6 & 37,2 \\
\hline 1 a 3 anos & 61 & 37,9 \\
\hline
\end{tabular}


Tabela 2 - Taxa de Atividade, segundo sexo e escolaridade (continuação)

\begin{tabular}{l|r|r}
\hline 4 a 7 anos & 66 & 42,1 \\
\hline 8 a 10 anos & 78,9 & 55,4 \\
\hline 11 a 14 anos & 89,2 & 73,3 \\
\hline \multicolumn{3}{|c|}{ (Brasil - 2005) } \\
\hline Escolaridade & Homens & Mulheres \\
\hline 15 ou mais & 89,1 & 82,8 \\
\hline Total & 73,6 & 52,9
\end{tabular}

Fonte: IBGE/Pnads:micro dados do período de 1995 - 2005.

Adaptado de: Bruschini; Ricoldi e Mercado (2008, p. 21).

A escolaridade elevada tem impacto considerável sobre o trabalho feminino, pois a taxa de atividade das mais instruídas são muito mais elevadas do que as taxas gerais de atividade, como pode ser observado em 2005, enquanto mais da metade (53\%) das brasileiras em geral eram ativas, entre aquelas com 15 anos ou mais de escolaridade a taxa de atividade atingiu (83\%).

Segundo Bruschini, Ricoldi e Mercado (2008), de todos os fatores relacionados à esfera produtiva, a presença de filhos pequenos é o que mais dificulta a atividade produtiva, porém, todas as mães, mesmo as com filhos muito pequenos, ampliaram sua presença no mercado de trabalho no período considerado.

Apesar do avanço verificado no período, as mulheres ainda estão longe de atingir as taxas masculinas de atividade, superiores a 70\%, e o número da PEA masculina e de ocupados. Cabe esclarecer que, segundo classificação de IBGE, a PEA inclui os ocupados e os desocupados. Os ocupados são aqueles que estão empregados, no trabalho formal ou informal, enquanto os desocupados são aqueles que estão à procura de emprego na ocasião da pesquisa.

Outro fator importante apontado nas pesquisas oficiais, no período de 1995 - 2005, é que as mulheres instruídas, além de continuar ocupando postos de trabalho em tradicionais "guetos" femininos, como magistério e a enfermagem, vêm marcando presença em áreas profissionais de prestígio, como a medicina, a advocacia, a arquitetura e até mesmo a engenharia, tradicional reduto masculino.

Tabela 3 - Participação feminina em ocupação de nível superior Brasil 1995 - 2005

\begin{tabular}{|c|c|c|}
\hline Ocupações de nível superior & Total & \% de mulheres \\
\hline \multicolumn{3}{|c|}{1995} \\
\hline Médicos & 146.141 & 37,7 \\
\hline Advogados & 20.160 & 37 \\
\hline
\end{tabular}


Tabela 3 - Participação feminina em ocupação de nível superior Brasil 1995 2005 (continuação).

\begin{tabular}{|c|c|c|}
\hline Procuradores e Advogados Públicos & 7.994 & 43 \\
\hline Magistrados & 10.991 & 24,2 \\
\hline Membros do Ministério Público & \multicolumn{2}{|c|}{0} \\
\hline Engenheiros & 130.225 & 11,6 \\
\hline Arquitetos & 7.121 & 51,9 \\
\hline \multicolumn{3}{|c|}{2005} \\
\hline Médicos & 226.021 & 39,8 \\
\hline Advogados & 42.724 & 45,6 \\
\hline Procuradores e Advogados Públicos & 7.241 & 42,3 \\
\hline Magistrados & 12.206 & 34,2 \\
\hline Membros do Ministério Público & 6.581 & 41,1 \\
\hline Engenheiros & 147.754 & 14,2 \\
\hline Arquitetos & 9.210 & 54,2 \\
\hline
\end{tabular}

Fonte: MTE/Rais, do período de 1995 - 2005.

Adaptado de: Bruschini; Ricoldi e Mercado (2008, p. 23).

Observa-se que mais de 54\% dos profissionais arquitetos são mulheres e as ocupações de nível superior de advogados, procuradores, membros do ministério público são em torno de 40\% dominados por trabalhadoras, ressaltando que em 1995 não havia nenhuma participação feminina em ocupação de nível superior como membro do ministério público.

Tanto a medicina quanto a arquitetura e a advocacia vêm passando por processos de especialização e assalariamento, em detrimento da antiga autonomia profissional. "As representações sociais, construídas pela sociedade e pelas próprias categorias, também estão se modificando, particularmente no que diz respeito ao seu perfil liberal, o que repercute no nível de prestígio e status atribuídos a esses profissionais” (BRUSCHINI; LOMBARD, 1999, 2000 apud BRUSCHINI; RICOLDI; MERCADO, 2008, p. 23).

Os dados das Pnads no período de 1995 a 2005 sinalizaram a persistência dos já conhecidos padrões diferenciados de inserção feminina e masculina segundo setores ou grupos de atividades econômicas. As trabalhadoras continuaram encontrando maiores oportunidades de trabalho, pela ordem, nos setores de prestação de serviços, agropecuárias, setor social, que na definição do IBGE são os serviços comunitários e sociais (médicos, odontológicos, veterinários e o ensino), comércio de mercadorias e indústria. A força de trabalho masculina manteve presença, pela ordem, na indústria, nos trabalhos ligados à agropecuária, no comércio de mercadorias na prestação de serviços. 
Tabela 4 - Distribuição dos ocupados, segundo sexo e setores de atividade. Brasil - 2005

\begin{tabular}{l|c|c}
\hline Setores de atividades & Homens & Mulheres \\
\hline Agrícola & 23,68 & 16,02 \\
\hline Indústria de transformação & 15,22 & 12,67 \\
\hline Construção & 10,88 & 0,4 \\
\hline Outras atividades industriais & 1,17 & 0,23 \\
\hline Comércio e reparação & 18,94 & 16,18 \\
\hline Alojamento e alimentação & 3,14 & 4,36 \\
\hline Serviços domésticos & 0,90 & 16,93 \\
\hline $\begin{array}{l}\text { Outros serviços coletivos, sociais e } \\
\text { pessoais }\end{array}$ & 2,71 & 5,26 \\
\hline Educação, saúde e serviços sociais & 3,44 & 16,14 \\
\hline $\begin{array}{l}\text { Transporte, armazenagem e } \\
\text { comunicação }\end{array}$ & 6,82 & 1,43 \\
\hline Administração pública & 5,22 & 4,45 \\
\hline Outras atividades & 7,51 & 5,88 \\
\hline $\begin{array}{l}\text { Atividades mal definidas ou não } \\
\text { declaradas }\end{array}$ & 0,36 & 0,04 \\
\hline Total (\%) & 100 & 100 \\
\hline Milhões & 50,40 & 36,6 \\
\hline
\end{tabular}

Fonte: IBGE/Pnads:micro dados do período de 1995 - 2005.

Adaptado de: Bruschini; Ricoldi e Mercado (2008, p. 25).

Ao analisar os dados constantes da Tabela 4, verifica-se que aproximadamente $40 \%$ das mulheres atuavam em três setores de atividades: “educação, saúde e serviços sociais”, "serviços domésticos” e "outros serviços coletivos, pessoais e sociais”, todos pertencentes ao setor de prestação de serviços.

Outro fator que por sua magnitude merece ser ressaltado são as denominadas ocupações precárias ou de má qualidade, que segundo Bruschini, Ricoldi e Mercado (2008) são caracterizadas pelas longas jornadas de trabalho, pelo baixo índice de registro em carteira de trabalho e pelos baixos rendimentos auferidos, observados nas ocupações das trabalhadoras domésticas, em atividades não remuneradas e aquelas exercidas na produção para o consumo próprio ou da unidade familiar, como ocorre na agricultura de subsistência.

Tabela 5 - Percentagem de participação das ocupações precárias femininas. Brasil - 1995 - 2005

\begin{tabular}{l|r|r}
\hline \multirow{2}{*}{ Setores de atividades precárias } & \multicolumn{2}{|c}{ Brasil } \\
\cline { 2 - 3 } & 1995 & 17,2 \\
\hline Trabalhadoras domésticas & 13,1 & 16,09 \\
\hline Não remuneradas & 9,3 & 9,0 \\
\hline $\begin{array}{l}\text { Consumo e construção próprios ou para o grupo } \\
\text { familiar }\end{array}$ & 39,60 & 7,3 \\
\hline Total (\%) & 32,39
\end{tabular}


Tabela 5 - Percentagem de participação das ocupações precárias femininas. Brasil - 1995 - 2005 (continuação)

\begin{tabular}{l|c|c}
\hline Números Absolutos de trabalhadoras domésticas & 4.782 .016 & 6.206 .202 \\
\hline $\begin{array}{l}\text { Números Absolutos de trabalhadoras não } \\
\text { remuneradas }\end{array}$ & 3.627 .608 & 3.310 .119 \\
\hline $\begin{array}{l}\text { Números Absolutos de trabalhadoras para o } \\
\text { consumo próprio }\end{array}$ & 2.578 .780 & 2.676 .778 \\
\hline
\end{tabular}

Fonte: IBGE/Pnads:micro dados do período de 1995 - 2005.

Adaptado de: Bruschini; Ricoldi e Mercado (2008, p. 27).

Depreende-se com base na análise dos dados da Tabela 5 que, em 2005, 33\% da força de trabalho feminina no Brasil, encontrava-se em nichos precários. Nicho ocupacional feminino por excelência, o emprego doméstico representa importante fonte, absorvendo 17\% da mão-de-obra feminina.

Ressaltam Bruschini, Ricoldi e Mercado (2008) que, embora ainda seja muito elevado, o percentual de trabalhadoras em ocupações precárias ou de má qualidade teve uma redução considerável ao longo do período, tendo sido registrado queda de 13\% para 9\% nas atividades não remuneradas e 9,3\% para 7,3\% em atividades para o próprio consumo. Segundo Bruschini (2007), esta redução talvez possa ser tomada como uma dimensão do avanço das mulheres, que estão ampliando sua participação no segmento formal do mercado.

Com relação aos dados estatísticos oficiais de 2008, a realidade do mercado de trabalho feminino manteve o mesmo perfil, conforme informações divulgadas no trecho abaixo:

\footnotetext{
Verifica-se que permanece a detecção de que há um longo caminho a percorrer para se chegar à igualdade entre os sexos, uma vez que "as mulheres são maioria da população e predominam entre os desocupados, mas ainda são menos numerosas que os homens na população ocupada: 44,4\%, ou 9,4 milhões de trabalhadores nas seis regiões metropolitanas investigadas pela Pesquisa Mensal de Emprego. Já o rendimento das trabalhadoras com nível superior equivale a $60 \%$ do recebido pelos homens com a mesma escolaridade. Ainda assim, entre as mulheres trabalhadoras, 59,9\% tinham 11 anos ou mais de estudo em janeiro de 2008, contra $51,9 \%$ dos homens. Por outro lado, enquanto o percentual de trabalhadoras com carteira assinada era de $\mathbf{3 7 , 8} \%$ entre os homens ele já atingia $48,6 \%$ em 2008”. (IBGE, 2008, p. 2).
}

No Gráfico a seguir encontram-se os comparativos da procura por emprego entre homens e mulheres nos períodos de janeiro de 2003 a janeiro de 2008. 


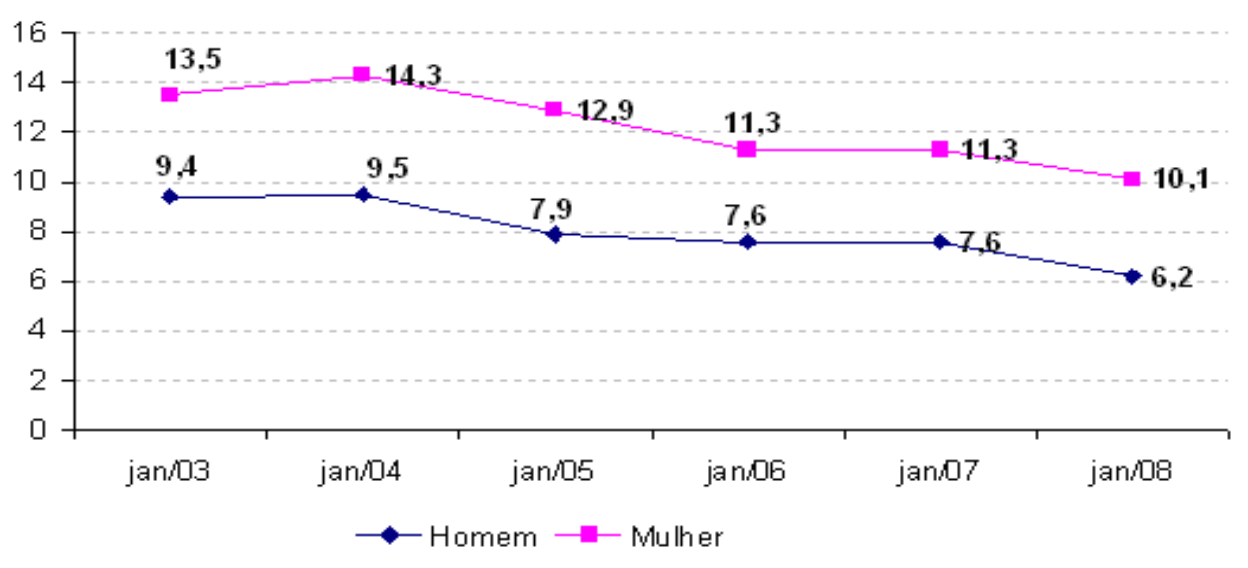

Gráfico 1 - Mulheres predominam entre os que procuram trabalho

Fonte: IBGE - (2008, p. 2)

Em janeiro de 2008, a taxa de desocupação entre as mulheres foi de 10,1\% e de 6,2\% entre os homens. Em relação a janeiro de 2003 observou-se queda na taxa de desocupação entre homens e mulheres, sendo que entre elas essa queda foi de 3,4 pontos percentuais, enquanto que entre os homens essa redução foi de 3,2 pontos percentuais, como mostra o Gráfico 1.

No Gráfico 2, são descritos o nível de escolaridade e a respectiva remuneração entre homens e mulheres em importantes capitais brasileiras

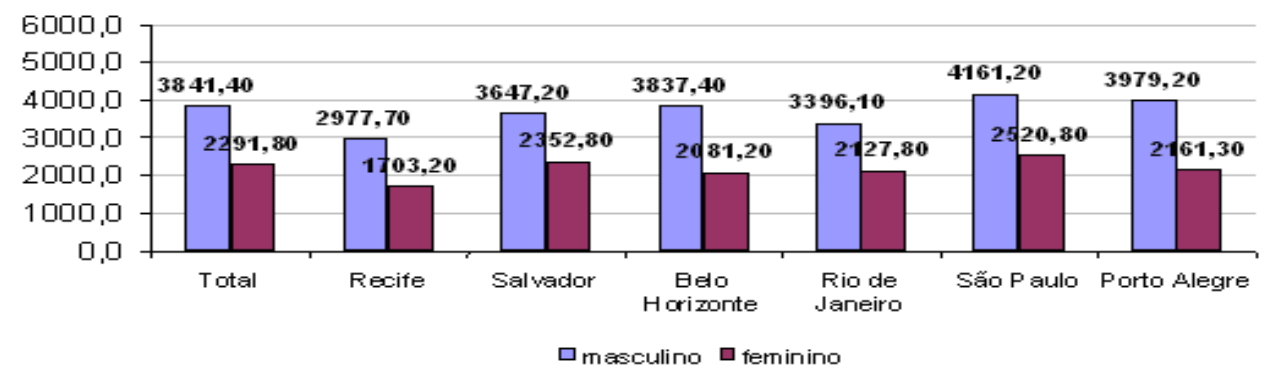

Gráfico 2 - Mulheres com nível superior recebem 60\% do rendimento dos homens

Fonte: IBGE - (2008, p. 3)

Ao analisar os dados divulgados referentes ao nível de escolaridade e a respectiva remuneração torna mais evidente a certeza de que há algo de errado para as mulheres que possuem nível superior completo, o rendimento médio habitual foi de R $\$ 2.291,80$ em janeiro de 2008; enquanto que para os homens esse valor foi de $\mathrm{R} \$ 3.841,40$. Ainda que comparando 
trabalhadores que possuem o nível superior, o rendimento das mulheres é cerca de $60 \%$ do rendimento dos homens, indicando que mesmo com grau de escolaridade mais elevado as discrepâncias salariais entre homens e mulheres não diminuem.

Uma iniciativa importante, recentemente tomada pela Secretaria Especial de Políticas para as Mulheres (SEPM) e pelo Conselho Nacional dos Direitos da Mulher, foi incluir como um dos temas centrais a ser discutido na II Conferência Nacional de Políticas para as Mulheres, o da participação das mulheres nos espaços de poder.

O VI relatório nacional brasileiro de 2007, publicado pela (SEPM), apresentou, dentre outros, estudos realizado no período de 2001 a 2005, relativo ao percentual de mulheres ocupando cargos nas instâncias superiores nos poderes judiciário, legislativo e executivo, conforme detalhado nas Tabelas a seguir.

Tabela 6 - Número de Ministros e Ministras

\begin{tabular}{l|c|c|c|c|c}
\hline \multirow{2}{*}{ Poder Judiciário } & \multicolumn{2}{|l|}{ Mulheres } & \multicolumn{2}{c|}{ Homens } & Total \\
\cline { 2 - 6 } & N.A. & $\%$ & N.A. & $\%$ & 100 \\
\hline $\begin{array}{l}\text { Supremo Tribunal } \\
\text { Federal }\end{array}$ & 2 & 18,18 & 9 & 81,82 & 11 \\
\hline $\begin{array}{l}\text { Superior Tribunal de } \\
\text { Justiça }\end{array}$ & 5 & 14,28 & 27 & 85,72 & 32 \\
\hline $\begin{array}{l}\text { Tribunal Superior do } \\
\text { Trabalho }\end{array}$ & 2 & 10,52 & 16 & 89,48 & 19 \\
\hline $\begin{array}{l}\text { Tribunal Superior } \\
\text { Eleitoral }\end{array}$ & 0 & 0 & 7 & 100 & 7 \\
\hline $\begin{array}{l}\text { Superior Tribunal } \\
\text { Militar }\end{array}$ & 1 & 6,66 & 15 & 93,44 & 15 \\
\hline Fon: SEPM (2007, p87) & & & & & \\
\hline
\end{tabular}

Fonte: SEPM (2007, p 87).

Da análise dos dados fica evidente o baixo percentual de mulheres na alta cúpula do poder judiciário, entretanto, de acordo com o Anuário da Justiça, (2008, p. 18) “De 92 nomes que compõem a cúpula do Judiciário, 13 são mulheres. Correspondem a 14\%, uma taxa modesta, sem dúvida, mas a mais elevada nos três poderes”.

Cabe ressaltar que de acordo com o Anuário da Justiça (2008) o Judiciário incorporou, em 2007, quatro novas ministras. Três foram nomeadas para o Tribunal Superior do Trabalho, totalizando 5 ministras e uma para o Superior Tribunal Militar, quebrando um tabu, depois de 200 anos de sua criação. Dos tribunais superiores, apenas o TSE não tem pelo menos uma mulher em sua composição, conforme se verifica na Tabela 6.

Com relação ao Poder Legislativo verifica-se que os percentuais de mulheres ocupando postos de trabalho nas instâncias superiores são bastante reduzidos. Na Câmara dos 
Deputados, a bancada feminina representa $9 \%$ e, no Senado, $12 \%$, conforme registros na Tabela 7 a seguir:

Tabela 7 - Mulheres em instâncias de Poder

\begin{tabular}{l|c|c|c|c|c}
\hline \multirow{2}{*}{ Poder Legislativo } & \multicolumn{2}{l|}{ Mulheres } & \multicolumn{2}{l|}{ Homens } & Total \\
\cline { 2 - 6 } & N.A. & $\%$ & N.A. & $\%$ & 100 \\
\hline Senado & 10 & 12,34 & 71 & 87,66 & 81 \\
\hline Câmara Federal & 45 & 8,77 & 468 & 91,23 & 513 \\
\hline $\begin{array}{l}\text { Assembléias } \\
\text { Estaduais }\end{array}$ & 123 & 11,61 & 936 & 88,39 & 1059 \\
\hline $\begin{array}{l}\text { Câmara de } \\
\text { Vereadores }\end{array}$ & 6.556 & 12,65 & 42.252 & 87,35 & 51.808 \\
\hline Fonte: SEPM (2007, p.84).
\end{tabular}

No Poder Executivo observa-se a mesmo o perfil de ocupação por mulheres de cargos de poder, ou seja, baixíssima representação feminina nos postos de comando. Segundo o Anuário da Justiça (2008), entre 27 governadores, há apenas 3 mulheres e nos 37 ministérios conta com apenas 3 mulheres.

Tabela 8 - Mulheres em instâncias de Poder

\begin{tabular}{l|l|l|l|l|l}
\multirow{2}{*}{ Poder Executivo } & \multicolumn{2}{|l|}{ Mulheres } & \multicolumn{2}{l|}{ Homens } & Total \\
\cline { 2 - 6 } & N.A. & $\%$ & N.A. & $\%$ & 100 \\
\hline $\begin{array}{l}\text { Presidência da } \\
\text { República }\end{array}$ & & - & 1 & 100,00 & 1 \\
\hline $\begin{array}{l}\text { Governo Estadual e } \\
\text { Distrital }\end{array}$ & 4 & 14,81 & 23 & 85,19 & 27 \\
\hline Prefeitura Municipal & 418 & 7,52 & 5.141 & 92,48 & 5.559 \\
\hline
\end{tabular}

Fonte: SEPM (2007, p 84).

Embora esses dados revelem o crescimento da força de trabalho feminina, sua trajetória ainda é marcada pela desigualdade de oportunidades ocupacionais relativamente à enfrentada pela população masculina.

Há preconceitos instalados nas entranhas organizacionais no que tange à ascensão profissional da mulher. O primeiro considerado tradicional, diz respeito às diferenças sexuais com base nas quais a empresa ainda vê como inferior e desigual para assumir postos de comando. O segundo, encontrado em empresas mais modernas em termos administrativos, é funcional, implicando desconfiança da disponibilidade do investimento da mulher no trabalho. (BETIOL; TONELLI, 1991 apud GRZYBOVSKI; BOSCARIN; MIGOTT, 2002, p. 192). 
2.3 A mulher no contexto organizacional: gestão da diversidade

Para se compreender como a mulher é tratada nas organizações faz-se necessário, primeiramente, entender como as organizações lidam com a diversidade como um todo.

Abordagens recentes expressam a necessidade de se levar em consideração o aumento da diversidade étnica e de gênero dentro das organizações (FLEURY, 2000). É importante ressaltar que esse aumento não se dê apenas em termos de aumento de representação das mulheres dentro das organizações, mas através da compreensão da importância da diversidade nas organizações, em se ter processos de admissão, promoção, exercício de funções e de remuneração mais justos, visando também o combate à discriminação dentro das organizações.

No Brasil, segundo Fleury (2000), o assunto diversidade é recente, surgiu nos anos 90, e ressalta que a grande maioria das companhias que estão desenvolvendo programas de gestão da diversidade é subsidiária de empresas norte-americanas, por pressão da matriz, preocupadas com a necessidade de gerar vantagens competitivas, apesar do contexto cultural diversificado em que atuam as empresas no Brasil.

\begin{abstract}
Os brasileiros valorizam sua origem diversificada, incluindo raízes africanas, presentes na música, na alimentação, no sincretismo religioso, gostam de se imaginar como uma sociedade sem preconceitos de raça ou cor. Mas por outro lado, é uma sociedade estratificada, em que o acesso às oportunidades educacionais e às posições de prestígio no mercado de trabalho é definido pela origem econômica e racial. (FLEURY, 2000, p. 19).
\end{abstract}

No setor público, a realidade não é diferente da mencionada por Fleury (2000), embora a diversidade de gênero, raça, origem, religião, deficiência física e muitos outros integrem os quadros funcionais dos órgãos, não existem registros, bancos de dados, que possibilitem a realização de estudos, elaboração de indicadores, muito menos, desenvolvimento de programas de gestão da diversidade.

A administração e a gestão de pessoas têm por missão contribuir para o desempenho da organização e a chave dessa performance está exatamente nos múltiplos comportamentos individuais e coletivos que regem a atividade global da organização, afirma Diniz (2006).

Considerando que as organizações trabalham com pessoas e que estas estão intimamente relacionadas com a formação, manutenção e alteração da cultura da instituição, é de se concluir que é imprescindível, para garantir a sobrevivência de qualquer empresa, 
repensar a questão da gestão das pessoas e de toda diversidade dela decorrente, como bem destacam os autores do trecho transcrito abaixo:

\begin{abstract}
As mudanças no perfil demográfico da sociedade e da força de trabalho lançam desafios para o gerenciamento das pessoas. A globalização econômica e de mercados também ampliou as possibilidades de se trabalhar com equipes mais heterogêneas quanto a nacionalidade, raça, hábitos e valores diferentes. Incorpore tudo isso ao fato de, hoje, as pessoas estarem mais cônscias de suas diferenças e desejarem vê-las respeitadas e valorizadas. (HANASHIRO; QUEIROZ, 2005, p.1).
\end{abstract}

Ainda, segundo Hanashiro e Queiroz (2005), muitos administradores têm patrocinado essas mudanças porque estão percebendo que os programas de diversidade ajudam, assegurando a criatividade, gerenciamento, valorização e influenciando a força de trabalho que conduzirá à eficiência organizacional e sustentará a competitividade. Mudanças que, segundo as autoras, não se caracterizam como modismo, mas é uma preocupação social, ética e moral, com reflexos dentro da organização.

Segundo Thomas (1996 apud FLEURY, 2000, p. 20) “a gestão da diversidade cultural implica adotar um enfoque holístico para criar um ambiente organizacional que possibilite a todos o pleno desenvolvimento de seu potencial na realização dos objetivos da empresa”.

A respeito da diversidade cultural, compreende-se que, mesmo com os divergentes posicionamentos, apresentam-se como fator positivo no avanço das conquistas sociais dos indivíduos e da sociedade em geral, uma vez que os desafios culturais atuam como fator de desenvolvimento, como expressa a Declaração Universal da Diversidade Cultural, promulgado através da Conferência Geral da UNESCO:

\footnotetext{
A diversidade cultural amplia as possibilidades de escolha que se oferecem a todos; é uma das fontes do desenvolvimento, entendido não somente em termos de crescimento econômico, mas também como meio de acesso a uma existência intelectual, afetiva, moral e espiritual satisfatória. (UNESCO, 2002, p. 2).
}

Ainda de acordo com a Declaração, e atentando-se às diferenças sociais, mais especificamente à diferença de sexo, defendendo e promovendo uma posição inclusiva e igualitária de direitos à mulher, expõe-se que:

Em nossas sociedades cada vez mais diversificadas, torna-se indispensável garantir uma interação harmoniosa entre pessoas e grupos com identidades culturais a um só tempo plurais, variadas e dinâmicas, assim como sua vontade de conviver. As políticas que favoreçam a inclusão e a participação de todos os cidadãos garantem a coesão social, a vitalidade da sociedade civil e a paz. Definido desta maneira, o pluralismo cultural constitui a resposta política à realidade da diversidade cultural. Inseparável de um contexto democrático, o pluralismo cultural é propício aos 
intercâmbios culturais e ao desenvolvimento das capacidades criadoras que alimentam a vida pública. (UNESCO, 2002, p. 1).

Ao analisar a trajetória da mulher, seja no contexto social, pessoal, familiar, profissional observa-se uma dinâmica constante de crescimento e de conquistas.

Os registros de transformações demográficas, culturais e sociais demonstram nova postura da mulher ao constatar constante queda na taxa de fecundidade, redução no tamanho dos arranjos familiares, crescimento acentuado de famílias chefiadas por mulheres, expansão da escolaridade e crescente aumento da participação da mulher no mercado de trabalho.

2.4 Análise de pesquisas científicas sobre gênero e trabalho

Segundo Zauli-Fellows (2006, p. 21) realizou a pesquisa objetivando responder à seguinte pergunta: “Qual é a percepção dos funcionários da Câmara dos Deputados quanto às oportunidades que a Mulher tem de ascensão na carreira”? Para responder à questão ZauliFellows (2006) realizou pesquisa de campo entre os meses de novembro de 2005 e janeiro de 2006, e a amostra abrangeu 1.320 respondentes.

Construiu-se survey para analisar a atitude dos respondentes em relação às possibilidades e aos limites de ascensão da Mulher na estrutura de cargos da organização, denominado Escala de Percepção de Igualdade de Oportunidades entre Mulheres e Homens. O questionário constou de 34 itens atitudinais, com escala de resposta Likert, e 7 itens sobre dados demográficos.

A coleta de dados, do tipo censitária, foi feita por meio da rede interna de computadores da Câmara dos Deputados, e o questionário foi enviado por e-mail aos 3.597 servidores do Quadro Efetivo da organização. Com o SPSS v.12.0, os dados foram submetidos à análise fatorial que evidenciou a presença de quatro fatores conforme a seguir:

- Fator 1: percepção do exercício por Homens de cargo de direção. (razões da ocupação de cargo de direção por Homens);

- Fator 2: percepção de treinamento e desenvolvimento. (realização de gestão de desempenho dos colaboradores, do trabalho em equipe e crença pela organização no valor do desenvolvimento do colaborador);

- Fator 3: percepção do exercício por Mulheres de cargo de direção. (aspectos positivos do fato de ser Mulher, como sensibilidade, capacidade de liderança e comprometimento com o trabalho); 
- Fator 4: percepção do conservadorismo relativo às Mulheres. (aspectos negativos do fato de ser Mulher e descrença da Mulher na respectiva competência).

Após essa etapa, segundo Zauli-Fellows (2006), puderam ser observadas diferenças entre Mulheres e Homens quanto aos escores obtidos, conforme trecho a seguir:

\footnotetext{
Verificou-se que as oportunidades de ocupar cargo de direção são menores para as Mulheres do que para os Homens, e, além de haver maior quantidade de gerentes do sexo masculino, os servidores, em especial as Mulheres que não ocupam posto de mando, percebem que não há igualdade de oportunidades entre funcionários de ambos os sexos. (ZAULI-FELLOWS, 2006, p. 8).
}

Segundo Zauli-Fellows (2006) as características da amostra analisada indicaram a maioria de mulheres, com média geral de idade de 43 anos e escolaridade geral de nível superior completo. A maioria dos participantes eram pessoas casadas, que não exerciam cargo de direção.

É importante registrar, já que a escala "Percepção de Igualdade de Oportunidades entre Mulheres e Homens” validada por Zauli-Fellows (2006) foi utilizada nesta pesquisa realizada no Tribunal (APÊNDICE A), que "Na análise com quatro fatores, apenas o Item 1 não apresentou carga maior ou igual a 0,30 e, por isso, foi retirado da escala”. (ZAULIFELLOWS, 2006, p. 113). Ou seja, o quantitativo de questões atitudinais constante no questionário de pesquisa aplicado na Câmara do Deputados, após criteriosa análise, foi alterado de 34 para 33 itens, impacto que foi considerado na análise dos resultados da pesquisa no Tribunal.

Foi objeto de análise, também, pesquisa qualitativa realizada por Aguiar (2007), cujo objetivo foi verificar qual a percepção das mulheres sobre os desafios em ser mulher em uma instituição financeira brasileira e se insere na área dos estudos organizacionais que trata das questões referentes às relações de gênero no ambiente de trabalho.

As informações que compõem esta pesquisa, segundo Aguiar (2007) foram coletadas por meio de entrevistas, não estruturadas e individuais com 10 ocupantes de cargos gerenciais e 10 analistas não ocupantes de cargos de comando. Das 20 entrevistadas, somente uma pessoa tinha menos de 14 anos de atuação na organização, 9 eram casadas, 7 eram solteiras e 4 separadas.

Segundo Aguiar (2007, p. 1) [...] "buscou-se compreender como as mulheres se percebem em uma organização bancária e como lidam com os diversos desafios que lhe são 
apresentados, desde a concorrência acirrada com os homens até à difícil conciliação da vida profissional com a pessoal”.

Após análise dos dados Aguiar (2007) concluiu que:

\begin{abstract}
Nesta pesquisa foi possível verificar que para uma mulher ter sucesso em uma instituição financeira, ela precisa provar dia a dia que é muito competente, mais que seus colegas homens e que o grande desafio da mulher em um banco é fazer tudo que os homens fazem, só que melhor que eles, não deixando de lado características próprias femininas. Também foi identificada a necessidade da organização definir e praticar políticas mais claras em relação à valorização da diversidade e, em especial, a valorização da mulher. (AGUIAR, 2007, 13)
\end{abstract}

Ao analisar as pesquisas realizadas por Zauli-Fellows (2006) e Aguiar (2007), observa-se que, embora tenham estudado instituições com características muito diferentes como é o caso do setor financeiro, considerado um reduto masculino, e Câmara dos Deputados, órgão do Poder Legislativo, as conclusões demonstraram que as dificuldades enfrentadas pelas mulheres no ambiente de trabalho são semelhantes.

Conclusões que geraram interesse nessa pesquisadora em conhecer a realidade e a percepção dos servidores do Tribunal com relação à igualdade de oportunidades entre os homens e mulheres que lá atuam, bem como comparar os resultados obtidos no Tribunal com os resultados de pesquisa realizada nos principais órgãos do Poder Judiciário brasileiro.

A metodologia a ser adotada para alcançar os objetivos aqui expostos é apresentada no capítulo seguinte. 


\section{METODOLOGIA}

Este capítulo tem por objetivo descrever os aspectos metodológicos da pesquisa empírica sobre igualdade de oportunidades entre homens e mulheres em um órgão do Poder Judiciário Brasileiro.

\subsection{Caracterização da Pesquisa}

A pesquisa realizada foi quantitativa e descritiva, pois a partir do método Survey buscou descrever a percepção dos servidores com relação à igualdade de oportunidades entre homens e mulheres na ocupação de funções e cargos comissionados. Segundo Vergara (2007, p. 47) “a pesquisa descritiva expõe características de determinada população ou de determinado fenômeno, podendo estabelecer correlações entre variáveis e definir sua natureza, sem o compromisso de explicar os fenômenos que descreve, embora sirva de base para tal explicação”.

Foi realizada, ainda, pesquisa em sistema de gestão de recursos humanos do Tribunal com o objetivo de melhor compreender a evolução histórica das oportunidades de ocupação dos cargos e funções comissionadas por servidores homens e mulheres no órgão em estudo.

Com o objetivo de ampliar e melhor compreender a realidade atual foi realizada pesquisa documental a partir de levantamento dos quantitativos de servidores, do número de cargos e funções comissionadas e percentuais de ocupação por mulheres e homens nos principais órgãos que compõem o Poder Judiciário Brasileiro. Os dados foram coletados, trabalhados, analisados e transformados em informações, gráficos com o auxílio das ferramentas Office Excel 2007 e SQL - Server 2000 Enterprise Edition.

\subsection{Caracterização da organização estudada}

A pesquisa de campo foi realizada em um órgão que compõe o Poder Judiciário brasileiro. Criado pela Constituição Federal de 1988. É a corte responsável por uniformizar a interpretação da lei federal em todo o Brasil, seguindo os princípios constitucionais e a garantia e defesa do Estado de Direito. É a última instância da Justiça brasileira para as causas infraconstitucionais, não relacionadas diretamente à Constituição. Como órgão de 
convergência da Justiça comum, aprecia causas oriundas de todo o território nacional, em todas as vertentes jurisdicionais não-especializadas.

O órgão tem como missão processar e julgar as matérias de sua competência originária e recursal, assegurando a uniformidade na interpretação das normas infraconstitucionais e oferecendo ao jurisdicionado uma prestação acessível, rápida e efetiva. Os valores institucionais são: auto-desenvolvimento; comprometimento; cooperação; ética; inovação; orgulho institucional; presteza e transparência.

Com relação ao seu planejamento estratégico, o órgão analisado define pontos de atuação em que o êxito é fundamental para o cumprimento de sua missão, tais como: oferecer serviços com qualidade; ampliar a responsabilidade sócio-ambiental; elevar a produção de julgados; acelerar o trâmite processual; manter em patamares elevados o conceito do Tribunal perante a sociedade; contribuir para a modernização do judiciário; melhorar o clima organizacional; desenvolver competências, assegurar e gerir recursos orçamentários e financeiros.

\subsection{População e Amostra}

A população objeto deste estudo compõe-se de servidores do quadro efetivo, requisitados e sem vínculo que atuam em um órgão público do Poder Judiciário brasileiro, totalizando 2.793 servidores, dos quais 1.417 (51\%) são homens e 1.376 (49\%) mulheres, conforme Tabela a seguir:

\begin{tabular}{|c|c|c|c|c|c|}
\hline \multicolumn{3}{|c|}{$\begin{array}{c}\text { Quantitativo de Servidores no } \\
\text { Quadro de Pessoal }\end{array}$} & \multicolumn{2}{|c|}{$\begin{array}{c}\text { Percentual do Preenchimento } \\
\text { das vagas }\end{array}$} & \multirow{2}{*}{$\%$ Total } \\
\hline Homens & Mulheres & TOTAL & $\begin{array}{c}\text { Homens } \\
(\%)\end{array}$ & Mulheres (\%) & \\
\hline 1417 & 1376 & 2793 & $51 \%$ & $49 \%$ & $100 \%$ \\
\hline
\end{tabular}

Foram distribuídos um total de 400 formulários aos servidores do Tribunal, dos quais 163 foram respondidos por homens, 119 por mulheres, totalizando uma amostra de 282 respondentes e destes, apenas um sujeito deixou quatro questões sem resposta. Esse total corresponde a aproximadamente $10 \%$ da População

Para corroborar na fundamentação do presente trabalho foram realizadas pesquisas nos históricos dos provimentos dos cargos e funções comissionados e nas tabelas de lotações, desde a criação do Tribunal. 
3.4 Instrumentos de coleta de dados

Foi utilizado um instrumento denominado "Escala de Percepção de Igualdade de Oportunidade entre Homens e Mulheres”, construído e validado por Zauli-Fellows (2006).

Trata-se de um instrumento quantitativo, composto por 33 perguntas fechadas, a serem respondidas em uma escala Likert, de cinco pontos, variando de 1 a 5, em que 1 significa “Discordo totalmente” e 5, "Concordo totalmente”, conforme quadro a seguir:

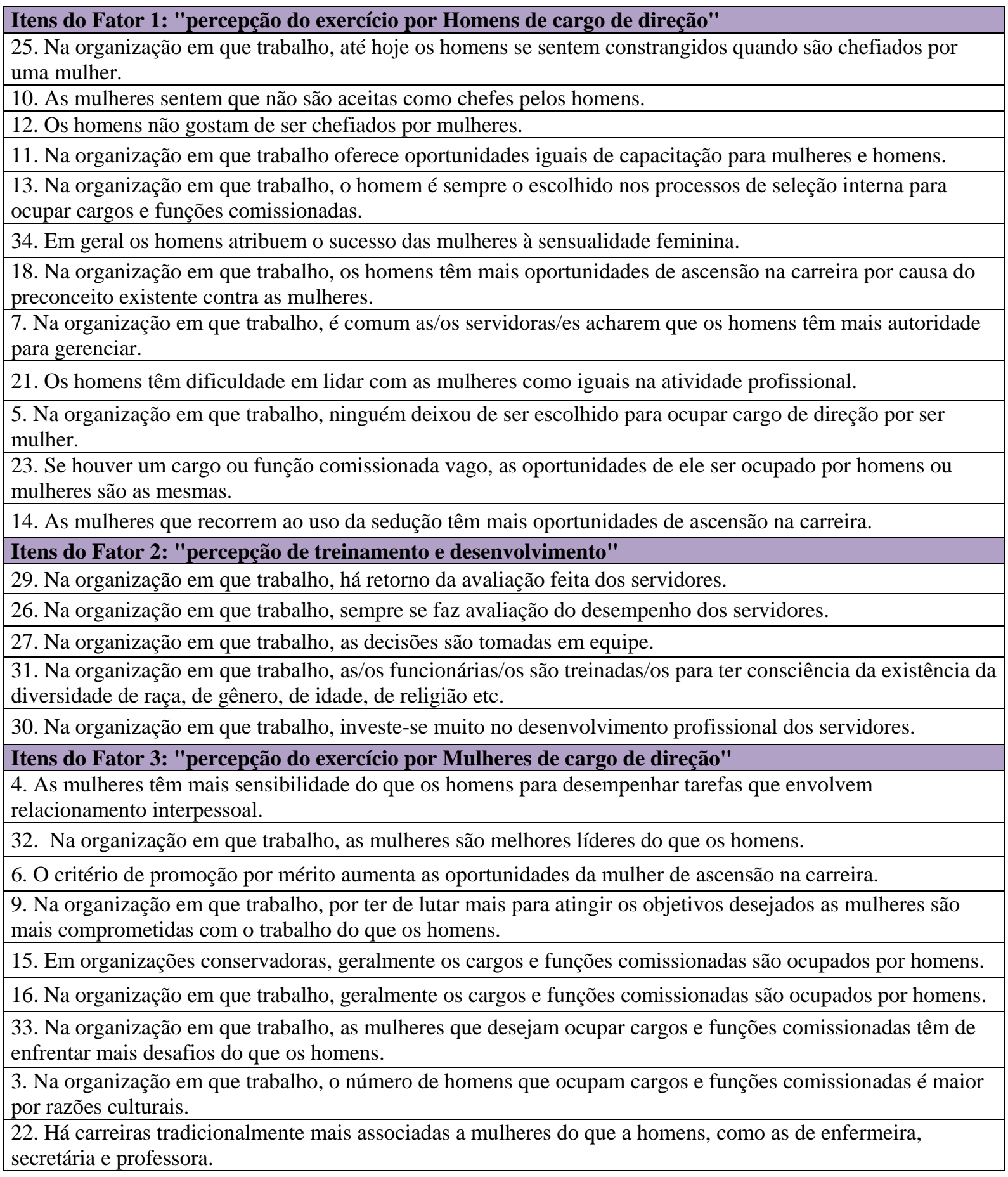


Itens do Fator 4: "percepção do conservadorismo relativo às Mulheres"

20. As mulheres têm medo de ocupar cargos e funções comissionadas.

8. Mesmo que tenham competência, as mulheres não desejam ocupar cargos e funções comissionadas.

2. As mulheres se consideram incapazes de ocupar cargos e funções comissionadas.

24. Por serem menos competitivas do que os homens, as mulheres não se candidatam a processos de seleção interna para ocupar cargos e funções comissionadas.

19. A organização em que trabalho nada pode fazer para que homens e mulheres tenham as mesmas oportunidades de ocupar cargos e funções comissionadas.

28. Na organização em que trabalho as mulheres são emocionalmente menos estáveis do que os homens.

17. Por achar que não serão escolhidas, as mulheres não se candidatam a processos de seleção interna para ocupar cargos e funções comissionadas.

Quadro 1: itens que compõem a Escala de Percepção de Igualdade de Oportunidade entre mulheres e homens

Além dos 33 itens da escala, constantes no Quadro 1, foram incluídas no questionário de pesquisa 10 questões demográficas pertinentes aos servidores do Tribunal, totalizando 43 questões.

E, com o intuito de ampliar o escopo do presente trabalho, foi elaborada e encaminhada planilha (ANEXO A), para os gestores da área de gestão de pessoas dos principais órgãos que compõem o Poder Judiciário brasileiro e solicitado que preenchessem os campos referentes ao quantitativo de servidores por sexo, número total de cargos e funções comissionadas do órgão e quantos estavam preenchidos por homens, mulheres ou vagos, de forma a possibilitar a realização de análises acerca da igualdade de oportunidades entre servidores homens e mulheres na ocupação dos postos de comando.

\subsection{Procedimentos de coleta de dados}

A pesquisadora contatou os gestores das unidades que compõem o órgão objeto do estudo e informou sobre a pesquisa que se pretendia realizar. Nessa ocasião, foi solicitada autorização para agendamento de visitas aos servidores. Na visita à unidade foi proferida breve explanação acerca da importância da pesquisa, orientação quanto ao preenchimento do questionário, garantia de sigilo e agendada data do recolhimento pela pesquisadora.

A autora do presente estudo reuniu-se com a gestora da unidade responsável pelos provimentos e vacâncias dos cargos e funções comissionados no órgão estudado,e, após apresentar detalhes sobre a pesquisa, solicitou que fosse disponibilizado histórico dos provimentos dos cargos e funções comissionadas, desde a criação do Tribunal

Para levantamento de dados junto aos demais órgãos foi realizado contato com os dirigentes das unidades de gestão de pessoas de cada órgão e, depois de prestados os devidos esclarecimentos, encaminhou-se, por e-mail, planilha com campos a serem preenchidos com o 
quantitativo de funções, cargos comissionados e respectivos percentuais de ocupação dos postos por servidores homens e mulheres.

\subsection{Análise dos dados}

Os questionários respondidos foram analisados, numerados e os dados lançados no software estatístico Statistical Package for the Social Sciences (SPSS) for Windows, versão 16.0, com o propósito de verificar a existência de diferentes percepções sobre a igualdade de oportunidades entre homens e mulheres, o que possibilitou extrair importantes reflexões acerca da organização estudada.

Foram calculadas as médias e desvios padrão dos fatores que compõem a Escala de Percepção de Igualdade de Oportunidade entre Homens e Mulheres. E, para melhor visualização e compreensão dos resultados da pesquisa, optou-se por detalhar a média e o desvio padrão dos itens que compõem cada fator.

Além disso, foram realizadas correlações entre os fatores e as variáveis demográficas (idade, estado civil, escolaridade, tipo de servidor, tipo de cargo ocupado e tempo de ocupação do cargo ou função comissionada). 


\section{APRESENTAÇÃO E DISCUSSÃO DOS RESULTADOS}

Neste capítulo, serão apresentados e discutidos os resultados do levantamento de dados (Survey) e da pesquisa documental realizadas no órgão estudado, bem como os decorrentes do levantamento realizado em importantes instituições que compõem o Poder Judiciário brasileiro.

É importante neste momento relembrar que o objetivo do presente estudo foi investigar a percepção dos servidores em termos de igualdade de oportunidades entre homens e mulheres na ocupação de cargos e funções comissionadas. Para tanto, foi utilizado instrumento de pesquisa denominado "Escala de Percepção de Igualdade de Oportunidade entre Mulheres e Homens”, construída e validada por Zauli-Fellows (2006).

Segundo Zauli-Fellows (2006. p.129) “a escala pode ser utilizada por qualquer organização que perceba a importância de ter um ambiente em que haja diversidade cultural e queira investigar a percepção dos respectivos trabalhadores quanto à igualdade de gênero”.

Conclui-se, portanto, que após análise dos dados coletados nesta pesquisa, é possível traçar um quadro de como uma amostra de servidores percebem a realidade do órgão em que trabalham.

Para facilitar a apresentação e discussão dos resultados optou-se por registrar as principais características demográficas dos respondentes como fonte de informação para reflexões: 58\% dos respondentes são do gênero masculino e 42 do gênero feminino, 65\% com mais de 36 anos, 60\% casados, 51\% com 1 ou 2 filhos, 89\% com no mínimo nível superior, 83\% com mais de 4 anos de Tribunal, 46\% ocupavam cargo ou função comissionada no momento da pesquisa e 64\% as ocupava por mais de 6 anos.

Primeiramente, serão apresentados e discutidos os resultados das pesquisas realizadas no órgão estudado e em seguida os resultados dos demais órgãos.

\subsection{Análises das médias dos fatores e dos itens}

Para facilitar a interpretação dos significados dos fatores, foi elaborada Tabela com médias e desvios padrão, em ordem decrescente, cujos valores se situaram entre 1 (discordo totalmente) e 4 (concordo), conforme detalhado a seguir. 
Tabela 10 - Ordem decrescente de médias e desvios dos fatores que compõem a Escala de Percepção de Igualdade de Oportunidade entre mulheres e homens

\begin{tabular}{c|c|c}
\hline FATORES & MÉDIA & DESVIO \\
\hline Fator 2 & 3,12 & 0,68 \\
\hline Fator 3 & 2,71 & 0,59 \\
\hline Fator 1 & 2,17 & 0,52 \\
\hline Fator 4 & 1,76 & 0,41 \\
\hline
\end{tabular}

As médias e desvios padrão registrados para o fator 2 denominado “percepção de treinamento e desenvolvimento” foi de 3,12, ou seja, número próximo de 3 (não discordo nem concordo). Com relação ao fator 3 "percepção do exercício por mulheres de cargo de direção" a média ficou entre 2 (discordo) e 3 (não discordo nem concordo). As médias dos fatores 1, e 4, denominados respectivamente de "percepção do exercício por homem de cargo de direção" e "percepção do conservadorismo relativo às mulheres" foram as que mais se aproximaram da discordância. A média do fator 2 situou-se próximo de 2 (discordo) e a do fator 4 entre 1 (discordo totalmente) e 2 (discordo)

Para melhor compreensão das respostas dos sujeitos em cada fator, a seguir serão detalhadas as médias e os desvios padrão dos itens que compõem cada fator.

4.2 Análises das médias dos itens que compõem os fatores

As tabelas com os valores das médias dos itens foram elaboradas seguindo a ordem decrescente de média registrada para cada fator, ou seja, primeiramente serão analisados os itens pertencentes ao fator 2, por ter sido o fator que registrou maior média.

Tabela 11: Valores das médias e desvios padrão calculados por item que compõem o Fator 2

\begin{tabular}{|c|c|c|}
\hline Itens do fator 2: “percepção de treinamento e desenvolvimento” & Média & Desvio \\
\hline $\begin{array}{l}\text { 26. Na organização em que trabalho, sempre se faz avaliação do desempenho dos } \\
\text { servidores. }\end{array}$ & 4,00 & 0,87 \\
\hline $\begin{array}{l}\text { 30. Na organização em que trabalho, investe-se muito no desenvolvimento profissional } \\
\text { dos servidores. }\end{array}$ & 3,66 & 0,99 \\
\hline 29. Na organização em que trabalho, há retorno da avaliação feita dos servidores. & 3,31 & 1,02 \\
\hline 27. Na organização em que trabalho, as decisões são tomadas em equipe. & 2,73 & 0,95 \\
\hline $\begin{array}{l}\text { 31. Na organização em que trabalho, as/os funcionárias/os são treinadas/os para ter } \\
\text { consciência da existência da diversidade de raça, de gênero, de idade, de religião etc. }\end{array}$ & 2,35 & 0,84 \\
\hline
\end{tabular}

O conjunto de itens que compõe o fator 2, "percepção de treinamento e desenvolvimento" expressa, segundo Zauli-Fellows (2006, p.115) “realização de gestão de 
desempenho dos colaboradores, do trabalho em equipe e crença pela organização no valor do desenvolvimento do colaborador”.

A média registrada no item 26 foi igual a 4 (concordo) e foi a que mais pesou na média do fator 2 (3,12). As médias dos itens 29 e 30 ficaram entre 3 (não discordo nem concordo) e 4 (concordo). Os itens 27 e 31 registraram médias entre 2 (discordo) e 3 (não discordo nem concordo). Observa-se que os respondentes tenderam a concordar mais com relação aos itens 26, 29 e 30, relacionados com a avaliação e desenvolvimento. Entretanto, em média, tenderam a discordar de que as decisões sejam tomadas em equipe ou que haja, por parte da organização, preocupação com a conscientização dos servidores com relação à diversidade.

Com relação ao item 31, verifica-se um alinhamento da percepção dos sujeitos da pesquisa com os estudos de Fleury (2000) ao afirmar que embora as empresas brasileiras atuem em um mercado cada vez mais diversificado não existe a cultura da gestão dessa diversidade.

Tabela 12 - Valores das médias e desvios padrão calculados por item que compõem o Fator 3

\begin{tabular}{|c|c|c|}
\hline Itens do Fator 3: “percepção do exercício por mulheres de cargo de direção” & Média & Desvio \\
\hline $\begin{array}{l}\text { 6. O critério de promoção por mérito aumenta as oportunidades da mulher de ascensão } \\
\text { na carreira. }\end{array}$ & 3,58 & 1,03 \\
\hline $\begin{array}{l}\text { 15. Em organizações conservadoras, geralmente os cargos e funções comissionadas são } \\
\text { ocupados por homens. }\end{array}$ & 3,51 & 0,87 \\
\hline $\begin{array}{l}\text { 22. Há carreiras tradicionalmente mais associadas a mulheres do que a homens, como as } \\
\text { de enfermeira, secretária e professora. }\end{array}$ & 3,42 & 1,04 \\
\hline $\begin{array}{l}\text { 4. As mulheres têm mais sensibilidade do que os homens para desempenhar tarefas que } \\
\text { envolvem relacionamento interpessoal. }\end{array}$ & 3,16 & 1,09 \\
\hline $\begin{array}{l}\text { 32. Na organização em que trabalho, as mulheres são melhores líderes do que os } \\
\text { homens. }\end{array}$ & 2,62 & 0,88 \\
\hline $\begin{array}{l}\text { 33. Na organização em que trabalho, as mulheres que desejam ocupar cargos e funções } \\
\text { comissionadas têm de enfrentar mais desafios do que os homens. }\end{array}$ & 2,43 & 1,00 \\
\hline $\begin{array}{l}\text { 3. Na organização em que trabalho, o número de homens que ocupam cargos e funções } \\
\text { comissionadas é maior por razões culturais. }\end{array}$ & 2,41 & 1,11 \\
\hline $\begin{array}{l}\text { 9. Na organização em que trabalho, por ter de lutar mais para atingir os objetivos } \\
\text { desejados as mulheres são mais comprometidas com o trabalho do que os homens. }\end{array}$ & 2,34 & 0,97 \\
\hline $\begin{array}{l}\text { 16. Na organização em que trabalho, geralmente os cargos e funções comissionadas são } \\
\text { ocupados por homens. }\end{array}$ & 2,13 & 0,79 \\
\hline
\end{tabular}

O fator 3, “percepção do exercício por mulheres de cargo de direção”, segundo ZauliFellows (2006, p.115) retrata "aspectos positivos do fato de ser mulher, como sensibilidade, capacidade de liderança e comprometimento com o trabalho”.

Os itens 4, 6, 15, e 22 registraram médias situadas entre 3 (não discordo nem concordo) e 4 (concordo) sendo o item 6 o que mais se aproximou da concordância. As 
médias dos itens 3, 9 e 16, 32 e 33, situaram-se entre 2 (discordo) e 3 (não discordo nem concordo), sendo o item 16 o que mais se aproximou da discordância.

Pode-se observar que os servidores tenderam a concordar mais com os itens que afirmam que a promoção por mérito aumenta a oportunidade de a mulher ascender na carreira; que em organizações conservadoras geralmente os cargos e funções são ocupados por homens; que há carreiras tradicionalmente mais associadas a mulheres do que a homens. Por outro lado, tenderam a discordar dos itens que afirmam que mulheres são melhores líderes do que os homens; que as mulheres que desejam ocupar cargos e funções comissionadas têm de enfrentar mais desafios dos que os homens; que o número de homens que ocupam cargos e funções comissionadas é maior por razões culturais; que, por ter que lutar mais para atingir os objetivos desejados as mulheres são mais comprometidas com o trabalho do que os homens e discordam, principalmente, de que geralmente os cargos e funções são ocupadas por homens.

Cabe salientar, com base nas médias dos itens 3, 9, 16, 32 e 33 da Tabela 12, que, a partir da percepção dos sujeitos da pesquisa parece não haver na organização, no momento pesquisado, distinção entre homens e mulheres em relação às oportunidades.

O fator 1 "percepção do exercício por homens de cargo de direção” expressa, segundo Zauli-Fellows (2006, p.115) “razões da ocupação de cargos de direção por homens”.

Tabela 13 - Valores das médias e desvios padrão calculados por item que compõem o Fator 1

\begin{tabular}{|c|c|c|}
\hline Itens do Fator 1: "percepção do exercício por Homens de cargo de direção" & Média & Desvio \\
\hline $\begin{array}{l}\text { 14. As mulheres que recorrem ao uso da sedução têm mais oportunidades de ascensão } \\
\text { na carreira. }\end{array}$ & 2,47 & 1,12 \\
\hline 12. Os homens não gostam de ser chefiados por mulheres. & 2,45 & 0,92 \\
\hline 34. Em geral os homens atribuem o sucesso das mulheres à sensualidade feminina. & 2,37 & 0,89 \\
\hline $\begin{array}{l}\text { 5. Na organização em que trabalho, ninguém deixou de ser escolhido para ocupar cargo } \\
\text { de direção por ser mulher. }\end{array}$ & 2,36 & 1,06 \\
\hline $\begin{array}{l}\text { 21. Os homens têm dificuldade em lidar com as mulheres como iguais na atividade } \\
\text { profissional. }\end{array}$ & 2,30 & 0,96 \\
\hline $\begin{array}{l}\text { 23. Se houver um cargo ou função comissionada vago, as oportunidades de ele ser } \\
\text { ocupado por homens ou mulheres são as mesmas. }\end{array}$ & 2,21 & 0,92 \\
\hline $\begin{array}{l}\text { 7. Na organização em que trabalho, é comum as/os servidoras/es acharem que os } \\
\text { homens têm mais autoridade para gerenciar. }\end{array}$ & 2,20 & 0,96 \\
\hline 10. As mulheres sentem que não são aceitas como chefes pelos homens. & 2,16 & 0,93 \\
\hline $\begin{array}{l}\text { 25. Na organização em que trabalho, até hoje os homens se sentem constrangidos } \\
\text { quando são chefiados por uma mulher. }\end{array}$ & 2,05 & 0,78 \\
\hline $\begin{array}{l}\text { 18. Na organização em que trabalho, os homens têm mais oportunidades de ascensão na } \\
\text { carreira por causa do preconceito existente contra as mulheres. }\end{array}$ & 1,86 & 0,75 \\
\hline $\begin{array}{l}\text { 13. Na organização em que trabalho, o homem é sempre o escolhido nos processos de } \\
\text { seleção interna para ocupar cargos e funções comissionadas. }\end{array}$ & 1,84 & 0,71 \\
\hline $\begin{array}{l}\text { 11. A organização em que trabalho oferece oportunidades iguais de capacitação para } \\
\text { mulheres e homens. }\end{array}$ & 1,73 & 0,84 \\
\hline
\end{tabular}


As médias dos itens 5, 7, 10,12, 14, 21,23, e 34 ficaram entre 2 (discordo) e 3 (não discordo nem concordo) sendo o item 34 o que mais pesou na média do fator. A média registrada para item 25 foi quase 2 (discordo) e os itens 11,13 e 18 registrou média entre 1 (discordo totalmente) e 2 (discordo) sendo o item 11 o que mais se aproximou da discordância total.

Verifica-se que os respondentes tenderam a discordar dos itens que compõem o fator 1, porém, discordaram mais com relação ao item 11, "Na organização em que trabalho oferece oportunidades iguais de capacitação para mulheres e homens” que, se comparada com a média do item 30, do fator 2 "Na organização em que trabalho, investe-se muito no desenvolvimento profissional dos servidores”, leva à conclusão de que os respondentes percebem que a organização investe em capacitação, mas não com igualdade de oportunidades entre homens e mulheres.

Ao analisar a média do item 23 evidencia-se, que os respondentes da pesquisa discordam que as oportunidades para cargos comissionados sejam as mesmas para homens e mulheres.

O fator 4 “percepção do conservadorismo relativo às mulheres” retrata, segundo ZauliFellows (2006, p.115) “aspectos negativos do fato de ser mulher e descrença da mulher na respectiva competência”.

Tabela 14 - Valores das médias e desvios padrão calculados por item que compõem o Fator 4

\begin{tabular}{l|c|c}
\multicolumn{1}{c|}{ Itens do Fator 4: “percepção do conservadorismo relativo às mulheres” } & Média & Desvio \\
\hline $\begin{array}{l}\text { 28. Na organização em que trabalho as mulheres são emocionalmente menos estáveis do } \\
\text { que os homens. }\end{array}$ & 2,37 & 0,93 \\
\hline $\begin{array}{l}\text { 19. A organização em que trabalho nada pode fazer para que homens e mulheres tenham } \\
\text { as mesmas oportunidades de ocupar cargos e funções comissionadas. }\end{array}$ & 1,79 & 0,79 \\
\hline $\begin{array}{l}\text { 8. Mesmo que tenham competência, as mulheres não desejam ocupar cargos e funções } \\
\text { comissionadas. }\end{array}$ & 1,70 & 0,77 \\
\hline $\begin{array}{l}\text { 24. Por serem menos competitivas do que os homens, as mulheres não se candidatam a } \\
\text { processos de seleção interna para ocupar cargos e funções comissionadas. }\end{array}$ & 1,70 & 0,57 \\
\hline $\begin{array}{l}\text { 17. Por achar que não serão escolhidas, as mulheres não se candidatam a processos de } \\
\text { seleção interna para ocupar cargos e funções comissionadas. }\end{array}$ & 1,68 & 0,55 \\
\hline 20. As mulheres têm medo de ocupar cargos e funções comissionadas. & 1,67 & 0,65 \\
\hline 2. As mulheres se consideram incapazes de ocupar cargos e funções comissionadas. & 1,44 & 0,66 \\
\hline
\end{tabular}

A média do item 28 situou-se entre 2 (discordo) e 3 (não discordo nem concordo) e foi o item que mais pesou na média do fator. As médias dos demais itens ficaram entre 1(discordo totalmente) e 2 (discordo) sendo as médias dos itens 2, 20 e 17 as que mais se aproximaram da discordância total. 
Percebe-se que em média os sujeitos tenderam a discordar com relação à "percepção do conservadorismo relativo às mulheres”.

Os respondentes da pesquisa revelaram não acreditar que a organização nada pode fazer para que homens e mulheres tenham as mesmas oportunidades, bem como discordam de que as mulheres têm medo ou se consideram incapazes de ocupar postos de comando.

\subsection{Análise das correlações entre os fatores e as variáveis independentes}

Ao adotar a técnica de correlação entre os quatro fatores e as variáveis independentes, sexo, idade, quantidade de filhos, escolaridade, área de atuação na organização, tempo de serviço, tempo de ocupação de cargo ou função comissionada, verificou-se apenas correlação significativa entre o fator 3 e a variável demográfica escolaridade.

A correlação demonstrou que os respondentes da pesquisa com maior grau de instrução tenderam a concordar mais que os com menor grau de instrução, com relação à percepção do exercício por mulher de cargo de direção, formado pelos seguintes itens da pesquisa:

1. O critério de promoção por mérito aumenta as oportunidades da mulher de ascensão na carreira.

2. Em organizações conservadoras, geralmente os cargos e funções comissionadas são ocupados por homens

3. Há carreiras tradicionalmente mais associadas a mulheres do que a homens, como as de enfermeira, secretária e professora.

4. As mulheres têm mais sensibilidade do que os homens para desempenhar tarefas que envolvem relacionamento interpessoal.

5. Na organização em que trabalho, as mulheres são melhores líderes do que os homens

6. Na organização em que trabalho, as mulheres que desejam ocupar cargos e funções comissionadas têm de enfrentar mais desafios do que os homens.

7. Na organização em que trabalho, o número de homens que ocupam cargos e funções comissionadas é maior por razões culturais.

8. Na organização em que trabalho, por ter de lutar mais para atingir os objetivos desejados as mulheres são mais comprometidas com o trabalho do que os homens.

9. Na organização em que trabalho, geralmente os cargos e funções comissionadas são ocupados por homens. 
As demais variáveis independentes não apresentaram correlações significativas com o fator 3 .

4.4. Apresentação e análise dos resultados da pesquisa realizada no Sistema de Administração de Recursos Humanos do órgão estudado. (SARH).

Foi realizada pesquisa de histórico de ocupação, por homens e mulheres, dos cargos e funções comissionadas na Instituição estudada com o propósito de complementar os resultados decorrentes das análises dos dados colhidos dos questionários.

Os Cargos Comissionados ou de Direção do Tribunal são escalonados de CJ-1 a CJ-4 e quanto maior o nível do CJ maior o valor da retribuição pecuniária paga a seu ocupante.

As Funções Comissionadas são escalonadas de FC-1 a FC-6 e quanto maior o nível da FC maior o valor pecuniário da retribuição.

Parte dos resultados do levantamento realizado possibilitou a elaboração da Tabela a seguir, que será fonte de análises e geração de gráficos que busquem facilitar a compreensão da história das ocupações dos cargos e funções por homens e mulheres no Tribunal.

Tabela 15 - Séries históricas de quantitativo e de percentual de ocupação de cargos comissionados por homens e mulheres no órgão estudado.

\begin{tabular}{l|c|c|c|c|c|c|c|c|c|c}
\hline & 1991 & 1993 & 1995 & 1997 & 1998 & 2000 & 2002 & 2004 & 2006 & 2008 \\
\hline Total Mulheres no STJ & 803 & 832 & 923 & 988 & 969 & 1068 & 1057 & 1177 & 1365 & 1376 \\
\hline MULHERES CJ & 126 & 132 & 132 & 131 & 143 & 150 & 162 & 177 & 189 & 185 \\
\hline $\begin{array}{l}\text { Mulheres CJ (\%) } \\
\text { Total de Homens no }\end{array}$ & $\mathbf{1 6 \%}$ & $\mathbf{1 6 \%}$ & $\mathbf{1 4 \%}$ & $\mathbf{1 3 \%}$ & $\mathbf{1 5 \%}$ & $\mathbf{1 4 \%}$ & $\mathbf{1 5 \%}$ & $\mathbf{1 5 \%}$ & $\mathbf{1 4 \%}$ & $\mathbf{1 3 \%}$ \\
\hline HTJ & 800 & 848 & 957 & 1044 & 1032 & 1120 & 1096 & 1190 & 1415 & 1415 \\
\hline Homens CJ (\%) & $\mathbf{1 2 \%}$ & 101 & 101 & 104 & 126 & 140 & 126 & 150 & 181 & 185 \\
\hline \begin{tabular}{l} 
TOTAL \\
\hline
\end{tabular} & 1603 & 1680 & 1880 & 2032 & 2001 & 2188 & 2153 & 2367 & 2780 & 2791 \\
\hline
\end{tabular}

Da análise dos dados constantes na Tabela acima, verifica-se que o quantitativo de servidores homens e mulheres se mantiveram muito próximos, embora se observe uma leve diferença a maior no quantitativo de homens. Entretanto, o percentual de ocupação dos cargos por mulheres supera o percentual dos homens, ao longo do período analisado. Diante do exposto, pode-se afirmar que, neste aspecto, sempre houve igualdade de oportunidade entre homens e mulheres, com uma leve vantagem para as mulheres. 


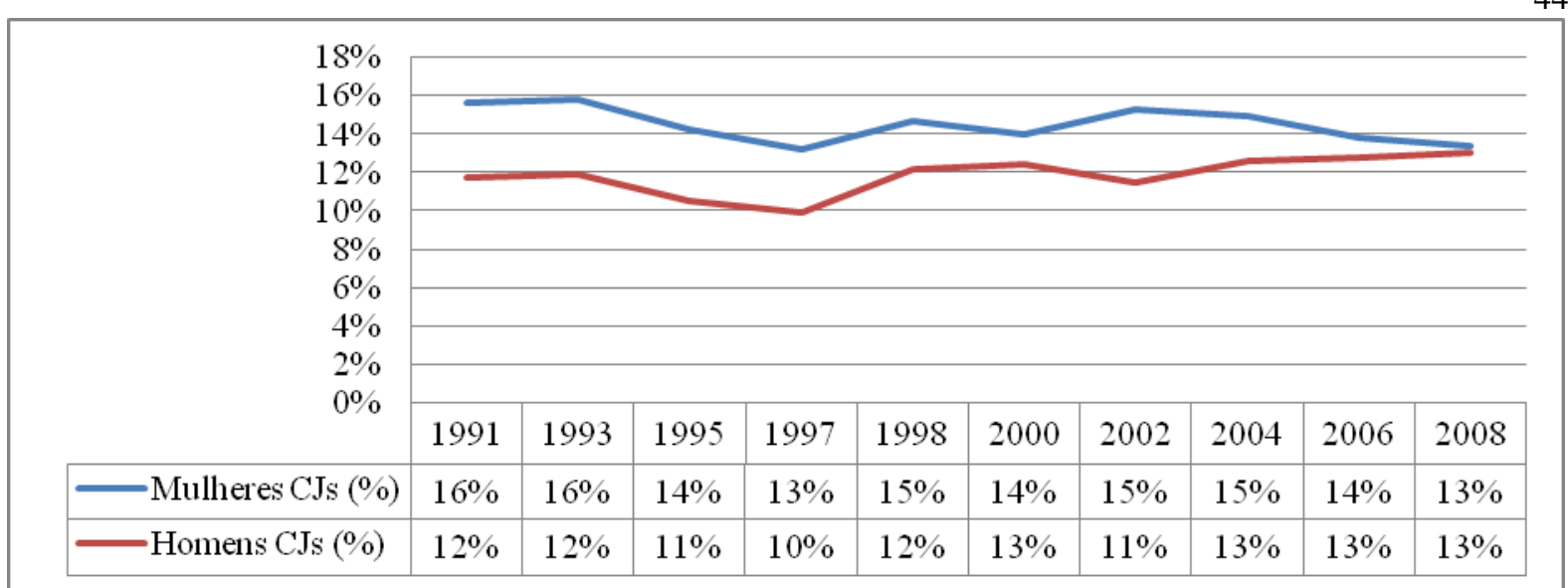

Gráfico - 3 Percentual de ocupação dos cargos comissionados por mulheres e homens

O gráfico 3 demonstra as alterações ao longo dos anos na ocupação dos cargos comissionados disponíveis no órgão e evidencia que os percentuais de ocupação por homens e mulheres foram sempre muito próximos, com predominância das mulheres até 2004, caindo essa diferença em 2006 até se igualar em 2008.

Cabe esclarecer que são consideradas funções comissionadas de natureza gerencial aquelas em que haja vínculo de subordinação e poder de decisão, especificados em regulamento, exigindo-se do titular participação em curso de desenvolvimento gerencial.

Tabela 16 - Séries históricas de quantitativo e de percentual de ocupação de funções comissionadas por homens e mulheres no órgão estudado.

\begin{tabular}{l|c|c|c|c|c|c|c|c|c|c} 
& 1991 & 1993 & 1995 & 1997 & 1998 & 2000 & 2002 & 2004 & 2006 & 2008 \\
\hline Total Mulheres no STJ & 803 & 832 & 923 & 988 & 969 & 1068 & 1057 & 1177 & 1365 & 1376 \\
\hline MULHERES FC & 397 & 397 & 428 & 470 & 275 & 298 & 282 & 312 & 349 & 366 \\
\hline Mulheres FC (\%) & $\mathbf{4 9 \%}$ & $\mathbf{4 8 \%}$ & $\mathbf{4 6 \%}$ & $\mathbf{4 8 \%}$ & $\mathbf{2 8 \%}$ & $\mathbf{2 8 \%}$ & $\mathbf{2 7 \%}$ & $\mathbf{2 7 \%}$ & $\mathbf{2 6 \%}$ & $\mathbf{2 7 \%}$ \\
\hline Total Homens no STJ & 800 & 848 & 957 & 1044 & 1032 & 1120 & 1096 & 1190 & 1415 & 1415 \\
\hline HOMENS FC & 320 & 381 & 448 & 493 & 340 & 323 & 339 & 358 & 398 & 418 \\
\hline Homens FC (\%) & $\mathbf{4 0 \%}$ & $\mathbf{4 5 \%}$ & $\mathbf{4 7 \%}$ & $\mathbf{4 7 \%}$ & $\mathbf{3 3 \%}$ & $\mathbf{2 9 \%}$ & $\mathbf{3 1 \%}$ & $\mathbf{3 0 \%}$ & $\mathbf{2 8 \%}$ & $\mathbf{3 0 \%}$ \\
\hline TOTAL & 1603 & 1680 & 1880 & 2032 & 2001 & 2188 & 2153 & 2367 & 2780 & 2791 \\
\hline
\end{tabular}

Da análise dos dados constantes na Tabela acima, verifica-se que o quantitativo de servidores homens e mulheres e o percentual de ocupação das funções se mantiveram muito próximos ao longo dos anos. A partir de 1998 o quantitativo de mulheres no quadro de pessoal reduziu e conseqüentemente, eles passaram a ocupar um número maior de funções comissionadas (FC-1 a FC-6).

Cabe esclarecer que os valores pecuniários atribuídos aos ocupantes dos cargos comissionados são maiores que os das funções comissionadas. 


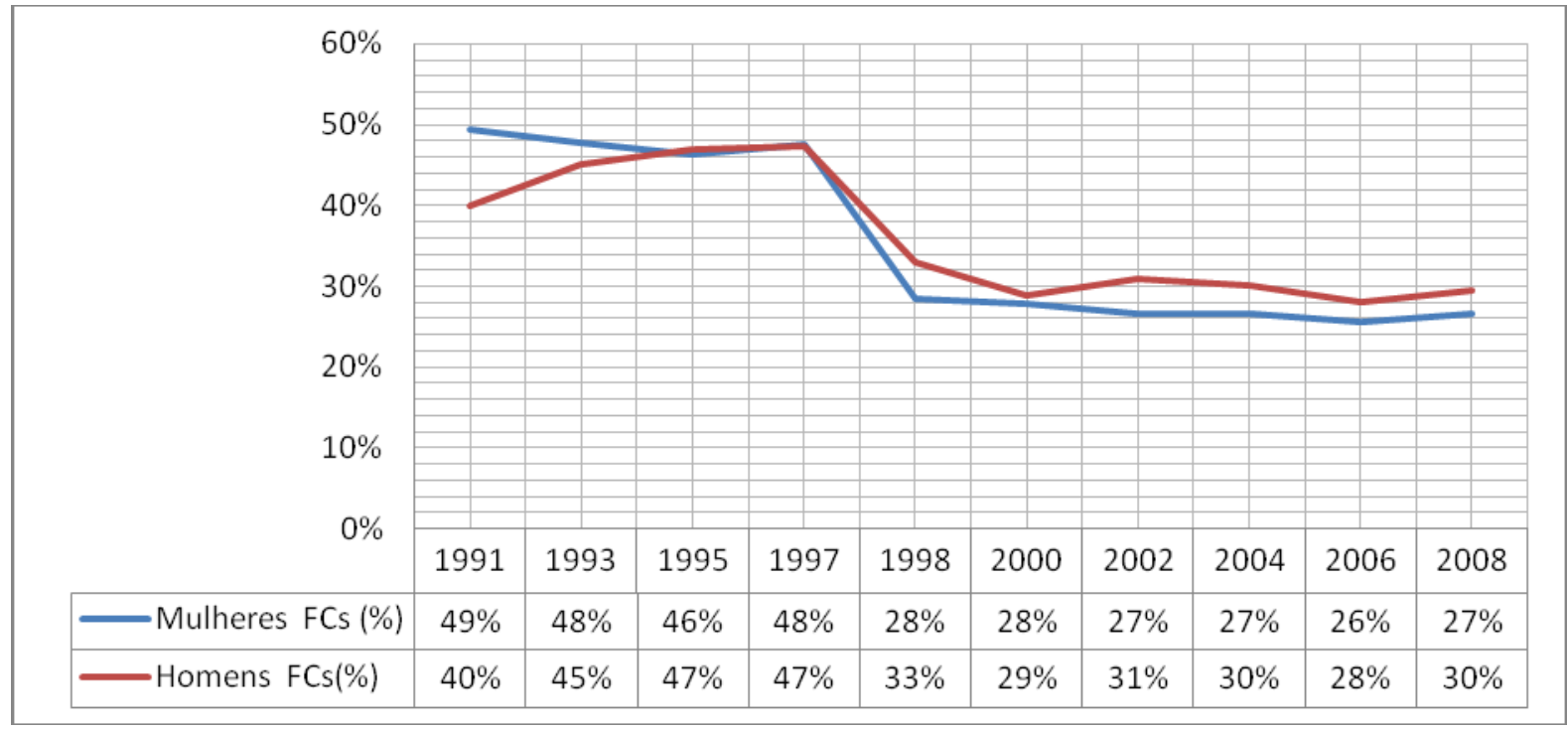

Gráfico - 4 Percentual de ocupação de funções comissionadas por homens e mulheres

O Gráfico acima evidencia que houve alterações ao longo dos anos na ocupação das funções comissionadas disponíveis no órgão e revela que os percentuais de ocupação por homens e mulheres foram sempre muito próximos, com uma ligeira predominância das mulheres até 1997, tendo os homens assumido percentual maior a partir de 1998.

Ao analisar os Gráficos 3 e 4, observa-se queda no percentual total das funções comissionadas a partir de 1997 e aumento, no mesmo ano, do percentual de cargos comissionados.

Cabe destacar que, ao analisar os itens 3 e 16 e respectivas médias, constantes na Tabela 12, e comparar com os dados registrados nas Tabelas 15 e 16, fica evidente o alinhamento entre a percepção dos servidores demonstrada na pesquisa de campo e o resultado da pesquisa documental.

Estes resultados encontram respaldo, entre outros aspectos, no fato de que algumas características específicas do setor público, tais como forma de ingresso, requisitos básicos de investidura, que, de certa forma impedem ou diminuem a ocorrência de discriminação ou preconceitos. Além disso, segundo Bruschine, Ricoldi e Mercado (2008) a crescente expansão da escolaridade a que as brasileiras têm cada vez mais acesso é um dos fatores de maior impacto sobre o ingresso das mulheres no mercado de trabalho, inclusive no setor público.

4.5 Apresentação e análise dos resultados da pesquisa nos principais órgãos do Poder Judiciário brasileiro 
Considerando que a análise objeto do presente estudo é verificar se há igualdade de oportunidades entre homens e mulheres na ocupação de postos de comando, foi realizada pesquisa junto aos principais órgão do Poder Judiciário, com o objetivo de evidenciar a participação da mulher e do homem na ocupação dos cargos e funções comissionadas existentes atualmente nas respectivas instituições e comparar com a Instituição pesquisada, conforme Tabela e Gráficos a seguir.

Tabela 17 - Quantitativo de cargos e funções comissionadas e percentual de ocupação por servidores homens e mulheres em importantes órgãos do Poder Judiciário brasileiro.

\begin{tabular}{|c|c|c|c|c|c|c|c|c|}
\hline \multirow{2}{*}{ Órgão } & \multirow{2}{*}{ Cargos/Funções } & \multirow{2}{*}{$\begin{array}{c}\mathrm{N}^{\circ} \\
\text { vagas }\end{array}$} & \multicolumn{3}{|c|}{ Preenchimento das vagas } & \multicolumn{3}{|c|}{$\begin{array}{l}\text { Análise Percentual do } \\
\text { Preenchimento das vagas }\end{array}$} \\
\hline & & & Homens & Mulheres & NP $\left(^{*}\right)$ & $\begin{array}{l}\text { Homens } \\
(\%)\end{array}$ & $\begin{array}{l}\text { Mulheres } \\
\text { (\%) }\end{array}$ & NP (\%) \\
\hline \multirow{2}{*}{ STF } & TOTAL CJ & 157 & 77 & 77 & 3 & $49,04 \%$ & $49,04 \%$ & $1,91 \%$ \\
\hline & TOTAL FC & 417 & 190 & 218 & 9 & $45,56 \%$ & $52,28 \%$ & $2,16 \%$ \\
\hline \multirow{2}{*}{ STJ } & TOTAL CJ & 390 & 188 & 185 & 17 & $48,21 \%$ & $47,44 \%$ & $4,36 \%$ \\
\hline & TOTAL FC & 810 & 418 & 367 & 25 & $51,60 \%$ & $45,31 \%$ & $3,09 \%$ \\
\hline \multirow{2}{*}{ TSE } & TOTAL CJ & 81 & 42 & 37 & 2 & $51,85 \%$ & $45,68 \%$ & $2,47 \%$ \\
\hline & TOTAL FC' & 277 & 127 & 148 & 2 & $45,85 \%$ & $53,43 \%$ & $0,72 \%$ \\
\hline \multirow{2}{*}{ TRF } & TOTAL CJ & 169 & 96 & 70 & 3 & $56,80 \%$ & $41,42 \%$ & $1,78 \%$ \\
\hline & TOTAL FC & 812 & 339 & 459 & 14 & $41,75 \%$ & $56,53 \%$ & $1,72 \%$ \\
\hline \multirow{2}{*}{ TRT } & TOTAL CJ & 96 & 56 & 40 & 0 & $58,33 \%$ & $41,67 \%$ & $0,00 \%$ \\
\hline & TOTAL FC & 975 & 383 & 505 & 87 & $39,28 \%$ & $51,79 \%$ & $8,92 \%$ \\
\hline \multirow{2}{*}{ TJDFT } & TOTAL CJ & 378 & 172 & 206 & 0 & $45,50 \%$ & $54,50 \%$ & $0,00 \%$ \\
\hline & TOTAL FC & 1681 & 685 & 996 & 0 & $40,75 \%$ & $59,25 \%$ & $0,00 \%$ \\
\hline \multirow{2}{*}{ CJF } & TOTAL CJ & 67 & 32 & 35 & & $47,76 \%$ & $52,24 \%$ & $0,00 \%$ \\
\hline & TOTAL FC & 129 & 66 & 61 & 2 & $51,16 \%$ & $47,29 \%$ & $1,55 \%$ \\
\hline \multirow{2}{*}{ TST } & TOTAL CJ & 268 & 99 & 137 & 32 & $36,94 \%$ & $51,12 \%$ & $11,94 \%$ \\
\hline & TOTAL FC & 2146 & 699 & 999 & 447 & $32,57 \%$ & $46,55 \%$ & $20,83 \%$ \\
\hline \multicolumn{2}{|c|}{ TOTAL GERAL } & 8853 & 3669 & 4540 & 643 & $41,44 \%$ & $51,28 \%$ & $7,26 \%$ \\
\hline
\end{tabular}

Do total de 574 cargos e funções comissionados existentes atualmente no STF 295 estão ocupados por mulheres e 267 por homens. Evidencia-se igualdade de oportunidades entre os servidores na ocupação das funções comissionadas (FC). Observa-se predominância de mulheres na ocupação dos cargos comissionados (CJ), hierarquicamente mais elevados. 

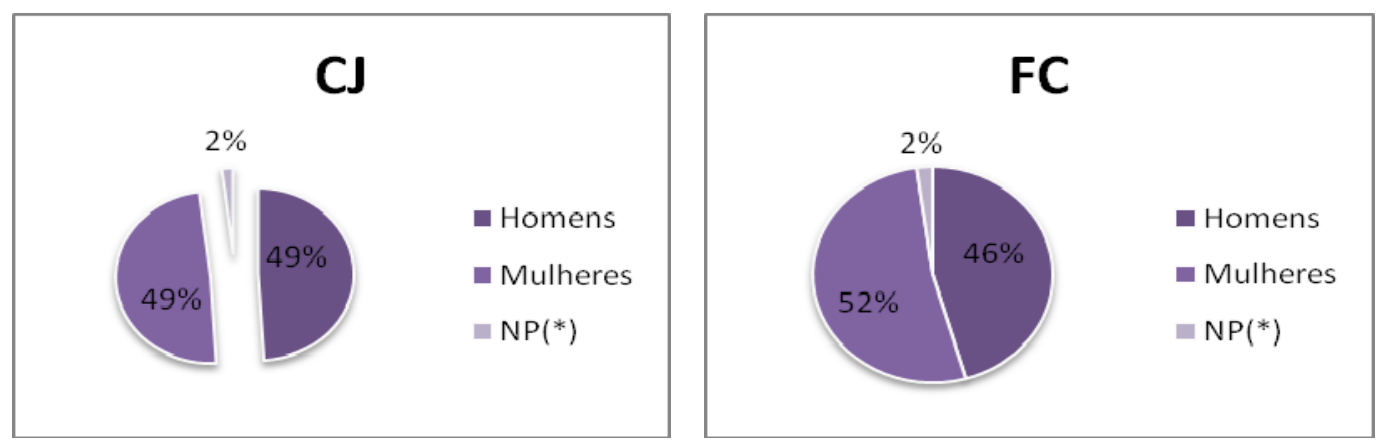

Gráfico - 5 Percentual de ocupação dos cargos (CJ) e funções comissionadas (FC) no STF em 2008

No STJ registra-se que dos 1.200 cargos e funções existentes 552 estavam ocupados por mulheres, 606 por homens e 42 estavam desocupados. O que demonstra igualdade de oportunidade entre homens e mulheres na ocupação dos postos de comando, conforme Gráficos a seguir:
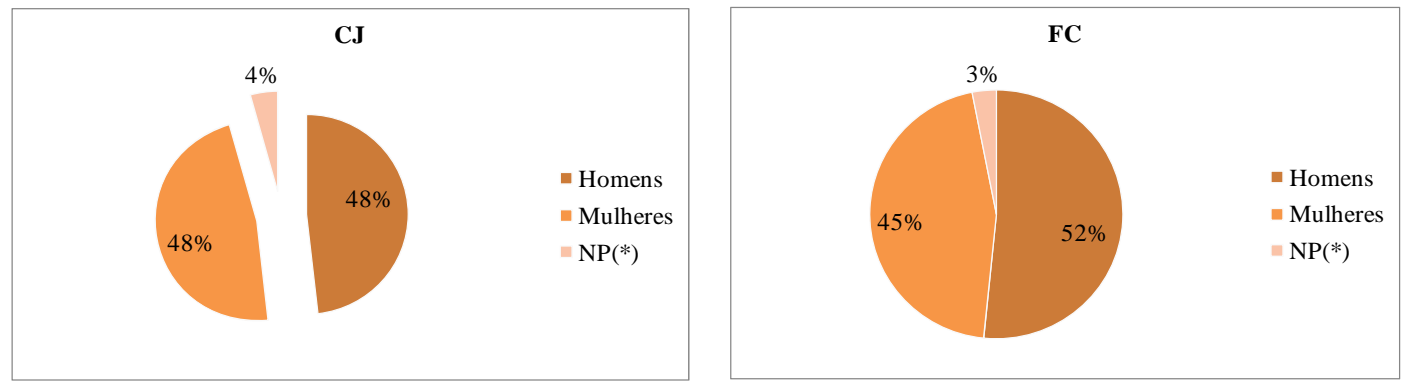

Gráfico - 6 Percentual de ocupação dos cargos e funções comissionadas no STJ em 2008

Com relação à disstribuição dos cargos e funções comissionadas no TSE, verifica-se que dos 358 postos de comando 185 eram ocupados por mulheres, 169 por homens e quatro estavam desocupados. O que demonstra no TSE que as mulheres, no ano de 2008, tiveram maior oportunidade que os homens na ocupação de postos de comando.
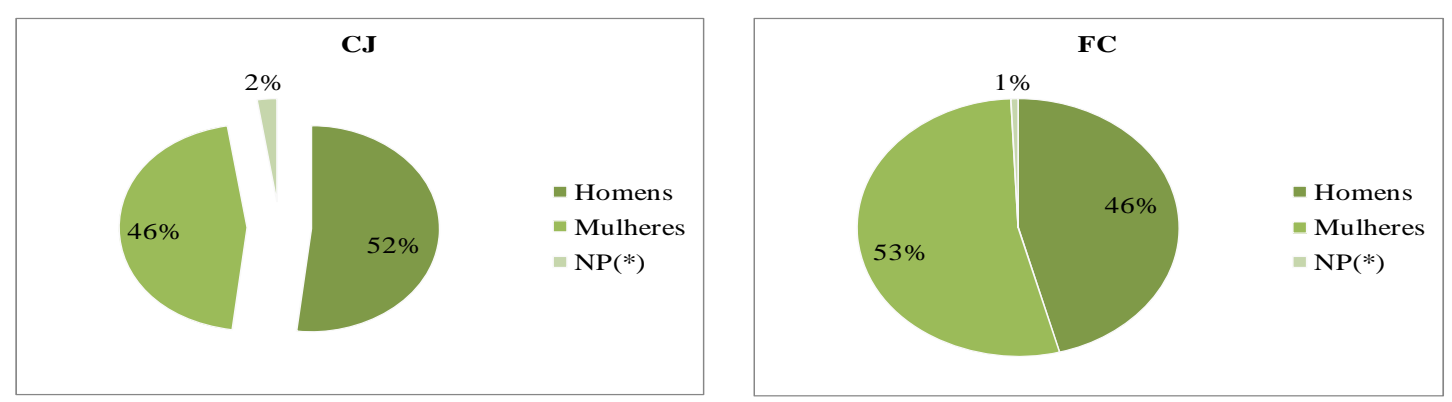

Gráfico - 7 Percentual de ocupação dos cargos e funções comissionadas no TSE em 2008 
No TRF, registra-se que dos 981 cargos e funções existentes 529 eram ocupados por mulheres, 435 por homens e 17 estavam desocupados. Observa- se ainda que há maior número de mulheres ocupando funções comissionadas do que homens.
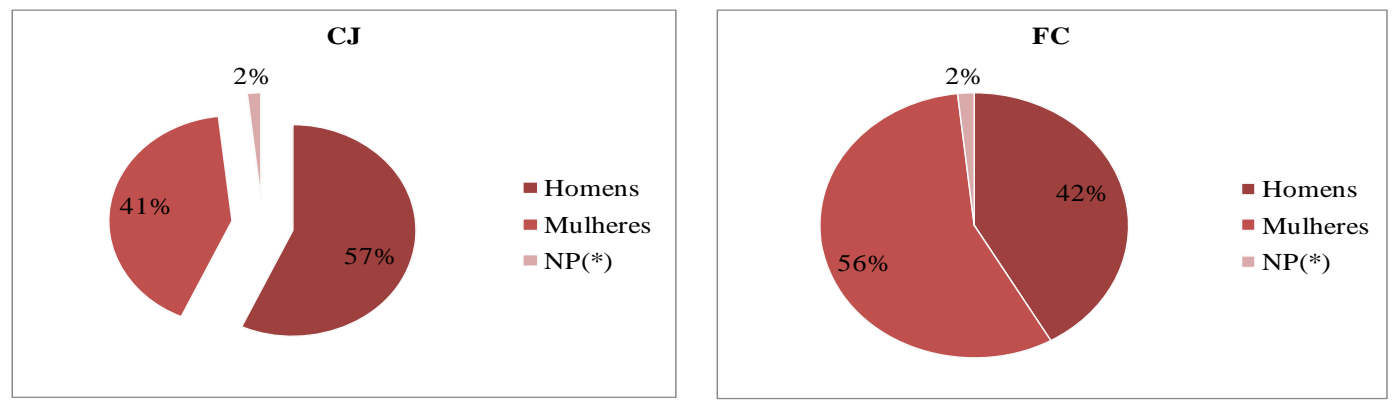

Gráfico - 8 Percentual de ocupação dos cragos e funções comissionadas no TRF

Verifica-se no TRT que dos 1.071 postos de comando 545 estavam ocupados por mulheres, 439 por homens e 87 estavam desocupados. O que demonstra que as mulheres, no ano de 2008, tiveram maior oportunidade que os homens na ocupação de postos de comando.
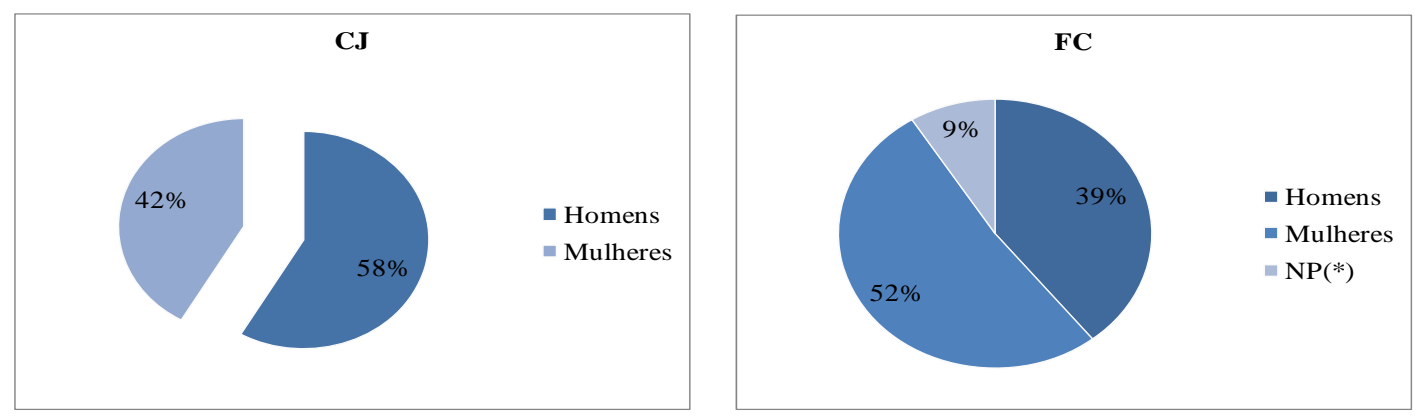

Gráfico - 9 Percentual de ocupação dos cargos e funções comissionadas no TRT em 2008

Do total de 2.059 cargos e funções comissionadas existentes em 2008 no TJDFT, 1.202 estavam ocupados por mulheres e 857 por homens. O que demonstra predominância das mulheres. Observa-se percentual maior de mulheres ocupando, inclusive, os cargos hierarquicamente mais elevados, conforme Gráficos a seguir:
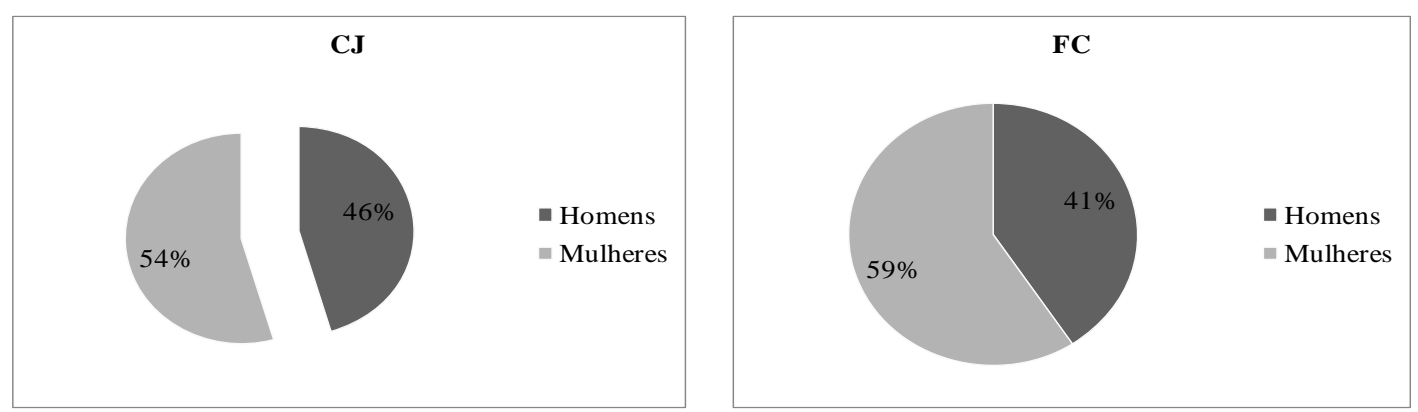

Gráfico - 10 Percentual de ocupação dos cargos e funções comissionadas no TJDFT em 2008 
Do total de 196 cargos e funções comissionadas existentes atualmente no CJF, 96 eram ocupados por mulheres, 98 por homens e 2 estavam desocupados. Verifica-se um percentual maior de mulheres nos cargos comissionados, postos hierarquicamente mais elevados, e percentual maior de homens nas funções, conforme Gráficos abaixo:
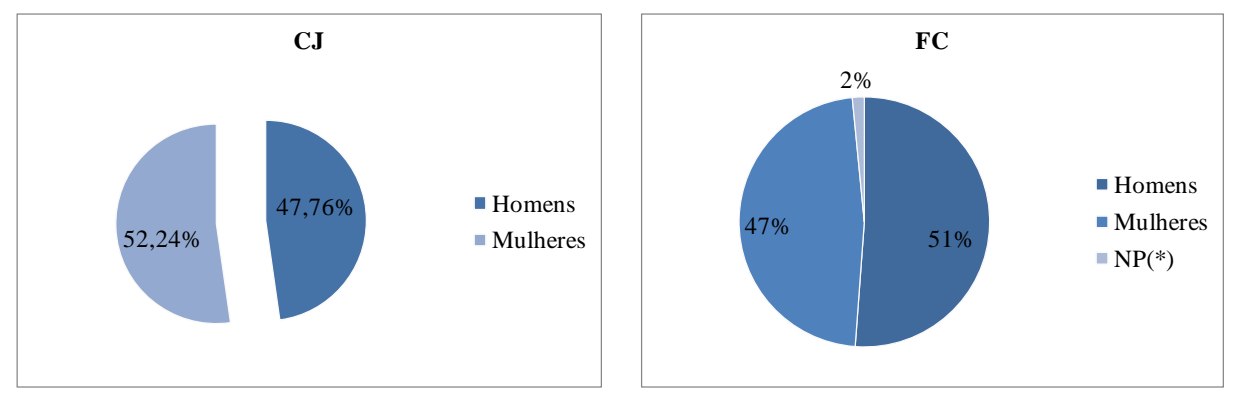

Gráfico - 11 Percentual de ocupação dos cargos e funções comissionadas no CJF em 2008

No TST dos 2.414 cargos e funções existentes 1.136 estão ocupados por mulheres, 798 por homens e 479 estão desocupados. Evidencia-se no TST que as mulheres estão tendo maiores oportunidades do que os homens com relação à ocupação de postos de comando em todos os níveis.
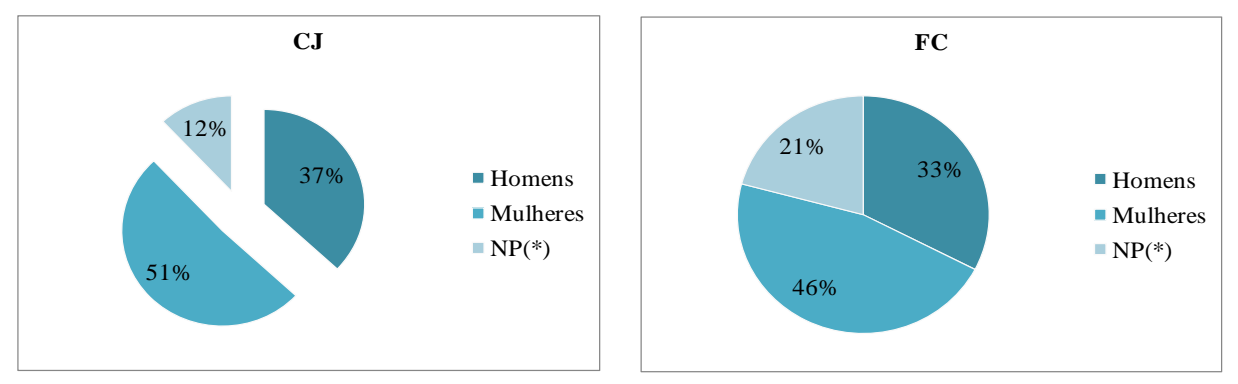

Gráfico - 12 Percentual de ocupação dos cargos e funções comissionadas no TST em 2008

Os resultados das pesquisas na Instituição estudada e junto aos principais órgãos do Poder Judiciário revelaram que as mulheres praticamente dividem com os homens o quadro de pessoal dos Tribunais. E, se o percentual de ocupação de cargos e funções comissionadas fosse suficiente para confirmar a existência de igualdade de oportunidades entre homens e mulheres, o Poder Judiciário poderia ser exemplo de administração da gestão da diversidade de gênero. Ou talvez, os papéis se invertessem, seriam os homens que estariam lutando por igualdade de oportunidade.

Observa-se , ainda, com base nas médias dos itens que compõem o fator 4, Tabela 14, que a percepção dos servidores do órgão estudado denota coerência com os resultados da pesquisa documental apresentada na Tabela 17, onde se verifica que mais de $51 \%$ dos cargos 
e funções comissionadas existentes nos principais órgãos do Poder Judiciário estão preenchidos por mulheres. Cabe destacar entretanto que, embora os dados da pesquisa documental indiquem que não há desigualdade de oportunidades, em média, os participantes do estudo ainda percebem que as oportunidades de ocupar um posto de comando não são as mesmas para os homens e as mulheres que atuam no Tribunal. Ou seja, independentemente dos aspectos negativos, o fato é que as mulheres estão efetivamente ocupando os cargos e funções nos principais órgãos do Poder Judiciário brasileiro. 
A análise do referencial teórico do presente estudo, combinada com as pesquisas de dados e de campo realizadas permitem concluir que a mulher vem, ao longo de sua trajetória, adotando posturas que possibilitam, cada vez mais, assumir o "leme” de sua vida, tornando-a sujeito de sua própria história. Percebe-se que as mães educam suas filhas para que se tornem independentes: econômica, financeira e emocionalmente. A decisão de casar, morar sozinha, ter filhos, formação profissional, entre outras, é cada vez mais, lugar comum e uma escolha que a mulher moderna faz, ao invés de uma imposição social. É claro que, devidamente considerados os limites impostos pelo poder econômico e pela lenta e gradual mudança cultural que se processa na sociedade, historicamente machista. A realidade das mulheres de baixa renda e escolaridade não oferece as mesmas oportunidades de escolha que são apresentadas às de classes intermediárias e altas.

É possível inferir, pela evolução da inserção feminina nos espaços públicos, uma paulatina perda do conservadorismo nas relações de gênero nas sociedades, cujo processo se mostra mais acelerado quanto mais desenvolvida é a nação. Prova inequívoca disso é o fato de que nos Estados Unidos da América a legislação não mais permite a diferenciação de salários de acordo com o sexo.

O fato de que as mulheres predominam entre os que buscam trabalho demonstra uma maior conscientização acerca da importância de sua participação econômica na sociedade e o anseio de determinar o seu futuro. Não se pode prescindir, nos dias de hoje, da presença feminina no mercado de trabalho, tendendo ao crescimento dessa participação, principalmente nos postos de trabalho em que o critério de inserção baseia-se em processo seletivo, como observado nos órgãos públicos. O aumento da escolarização da mulher é fator determinante dos avanços de sua participação nos cargos oferecidos pelo serviço público, fenômeno particularmente evidenciado no âmbito do Poder Judiciário, objeto da presente pesquisa.

Nesse aspecto é notório observar diferenças existente na ocupação pela mulher dos postos de trabalho que impliquem conhecimento e competência e nos ditos "espaços de poder”, em que o critério básico é político. Naqueles, a presença feminina é crescente, enquanto nestes, ainda muito tímida, conforme se pode comparar a partir dos dados apresentados relativos aos órgãos do poder judiciário, de um lado, e legislativo e executivo de outro. 
No que tange à gestão da diversidade nas organizações, também objeto do presente estudo, percebe-se que as instituições tendem a implementar cada vez mais mudanças nos processos de trabalho, orientadas para essa questão, por reconhecerem o potencial de desenvolvimento e ganho qualitativo que estas mudanças podem favorecer. Avanços qualitativos podem ser observados no modelo de gestão adotado pelo órgão estudado, principalmente na questão de gênero, notadamente na igualdade observada no processo de capacitação e no preenchimento dos cargos e funções comissionados.

No entanto, a principal evidência apontada pela análise dos resultados da pesquisa de campo e dos dados institucionais apresentados neste trabalho, é de que o Poder Judiciário se mostra como uma instituição singular no que se refere ao tratamento dado à questão de gênero. Enquanto a mulher na sociedade em geral ainda sofre muitos preconceitos culturais e econômicos em sua inserção pelo mundo do trabalho, nestas instituições, sua posição é de grande avanço no que diz respeito ao reconhecimento de sua competência e nivelação salarial com o sexo oposto, inclusive em relação a outros órgãos do poder público. Senão vejamos.

Verifica-se que as mulheres que atuam no órgão estudado, se considerada a análise do quantitativo de postos de comando ocupados por elas como parâmetro suficiente para avaliar a questão da igualdade de oportunidades, fica evidente que as oportunidades foram oferecidas de forma equânime entre homens e mulheres, não apenas recentemente, mas ao longo da trajetória do Tribunal.

Observa-se que os servidores percebem que as mulheres estão ocupando os cargos e funções tanto quanto os homens, ou seja, percebem esta realidade ao demonstrarem tendência a discordar com relação às afirmações de que geralmente os cargos e funções comissionadas são ocupados por homens; de que as mulheres têm medo, são menos competitivas, sentem-se incapazes de ocupar cargos e funções.

Os servidores não têm dificuldade em lidar com as mulheres no comando pois tenderam a discordar de que as mulheres sentem que não são aceitas como chefes pelos homens; ou que os homens se sentem constrangidos quando são chefiados por uma mulher; que os homens têm mais oportunidade de ascensão na carreira por causa de preconceito existente contra as mulheres

Evidencia-se, também, que os servidores reconhecem nas mulheres características que contribuem para que elas estejam vivendo esta realidade ao tenderem a concordar que as mulheres são mais sensíveis do que os homens para desempenhar tarefas que envolvem relacionamento interpessoal, que há carreiras tradicionalmente mais associadas às mulheres, 
que o critério de promoção por mérito aumenta as oportunidades de a mulher ascender na carreira.

Fato é que, as mulheres que atuam nos principais órgãos do Poder Judiciário estão tendo oportunidades de ocupar os postos de comando tanto quanto os homens ou, em alguns casos mais que eles.

É importante considerar que o presente estudo apresenta limitações que precisam ser consideradas. Em função do curto espaço de tempo disponível para finalização dos trabalhos não foi possível construção de instrumento de pesquisa que considerasse a realidade do órgão objeto do estudo. Frise-se, entretanto, que foi utilizado na consecução do estudo instrumento cientificamente validado e elaborado para o mesmo propósito, ou seja, a investigação da percepção dos servidores de determinado órgão do poder legislativo.

Outro aspecto a ser considerado é que em função do custo e do tempo, o tamanho da amostra na pesquisa de campo não pode ser considerado muito representativo, pois contou com aproximadamente $10 \%$ da população, o que não inviabiliza a realização da chamada estatística descritiva, permitindo tirar conclusões acerca da amostra estudada.

Por fim, é missão da presente pesquisa, apontar sugestões para projetos de estudos posteriores, cujos questionamentos afloraram das análises realizadas. Seria de suma importância investigar junto à área de gestão de pessoas se a realidade de avanço demonstrada foi refletida e planejada pela organização, ou trata-se de um fenômeno atípico? A organização adota ações de gestão de pessoas que proporcionam às servidoras conciliarem sua vida profissional e doméstica? Há acompanhamento da qualidade de saúde física e mental dessas profissionais? São adotadas ações que visem a conscientizar os servidores da importância da maior igualdade também no espaço privado? Outro aspecto importante a ser investigado diz respeito ao custo pessoal, emocional empreendido pela mulher para atingir este estágio e, principalmente, para mantê-lo.

Pretende-se que a presente pesquisa seja um singelo referencial para a busca de resposta para essas e tantas outras perguntas que se impõem na análise da realidade de gênero em nossa sociedade, principalmente no que diz respeito à busca da igualdade de oportunidades e de tratamento, respeitando a diversidade, tão salutar para o desenvolvimento saudável da vida social. 


\section{REFERÊNCIAS}

AGUIAR, G S. DE. Diversidade no Trabalho: os desafios em ser mulher em uma organização financeira. Dissertação (Mestrado em Administração). Programa de PósGraduação em Administração - Universidade de Brasília, Brasília, 2007.

ANUÁRIO DA JUSTIÇA. São Paulo: FAAP: 2008.

BEAUVOIR, S. Infância e a Moça. In:

O Segundo Sexo 2 - A experiência vivida. Tradução: Sérgio Milliet. 2. ed. Rio de Janeiro: Nova Fronteira: 1980. cap. 1.

BRASIL. Código Civil de 1916. 1916. Disponível em: http://www.planalto.gov.br: Acesso em: 22 jan. 2009.

BRASIL. Código Eleitoral de 1932. 1932. Disponível em: <http://www.planalto.gov.br>. Acesso em: 14 dez. 2008.

BRASIL. Constituição Federal de 1932. 1932. Disponível em: <http://www.planalto.gov.br>. Acesso em: 14 dez. 2008.

BRASIL. Constituição Federal de 1934. 1934. Disponível em: <http://www.planalto.gov.br>. Acesso em: 06 jan. 2009.

BRASIL. Constituição Federal de 1988. 2007. Disponível em: <http://www.planalto.gov.br>. Acesso em: 06 jan. 2009.

BRASIL. Estatuto da Mulher Casada 1962. 1962. Disponível em: <http://www.planalto.gov.br>. Acesso em: 08 jan. 2009.

BRASIL. Lei do Divórcio de 1977. 1977. Disponível em: <http://www.planalto.gov.br>: Acesso em: 06 jan. 2009.

BRASIL. Estatuto da Criança e do Adolescente de 1990. 2008. Disponível em: http://www.planalto.gov.br. Acesso em: 08 jan. 2009.

BRUSCHINI, C.; RICOLDI, A. M.; MERCADO C. M. Trabalho e gênero no Brasil até 2005: uma comparação regional. In: Mercado de Trabalho e Gênero. Rio de Janeiro: FGV, 2008. cap. 1.

BRUSCHINI, C. Trabalho e Gênero no Brasil nos últimos dês anos. Cadernos de Pesquisa, v. 37, n. 132, p. 1-33, set/dez. 2007. 
CLARA, A.; CELI, S. Percepções e atitudes de mulheres e homens sobre a conciliação entre família e trabalho pago no Brasil. In: Janeiro: FGV, 2007. cap. 1. . Gênero, família e trabalho no Brasil. Rio de

DEPARTAMENTO INTERSINDICAL DE ESTATÍSTICA E ESTUDOS SOCIOECONÔMICOS (DIEESE). Pesquisa de Emprego e Desemprego. 2007. Disponível em: http://www.dieese.org.br/ped/bd/mercadotrab.xml>. Acesso em: 15 out. 2008.

DINIZ, M. A. O Espelho não tem duas faces: um estudo entre a cultura e o clima organizacional na UFPB. In: ENCONTRO NACIONAL DOS PROGRAMAS DE PÓSGRADUAÇÃO EM ADMINISTRAÇÃO (ENAMPAD), 30, 2006, Salvador. Anais do XXX Encontro Nacional dos Programas de Pós-Graduação em Administração. Salvador, 2006.

DUALIBI, R. Um banco de frases para estimular sua criatividade. Phrase Book. São Paulo: Mandarim, 1996.

FLEURY, M. T; FISCHER, R. M. Cultura e poder nas organizações. 2. ed. São Paulo: Atlas, 1996.

FLEURY, M. T. L. Gerenciando a diversidade cultural: experiência de empresas brasileiras. RAE-Revista de Administração de Empresas, v. 40, n. 3, p. 18-25, jul./set. 2000.

GRZYBOVSKI, D; BOSCARIN, R; MIGOTT, A. M. B. Estilo feminino de gestão em empresas familiares gaúchas. Revista de Administração Contemporânea, v.6 n.2, maio/set. 2002, p. 185-205.

HANASHIRO, D. M. M.; GODOY, A. S. Um preâmbulo à gestão da diversidade: da teoria a prática. In: ENCONTRO NACIONAL DOS PROGRAMAS DE PÓS-GRADUAÇÃO EM ADMINISTRAÇÃO (ENANPAD), 28, 2004, Curitiba. Anais do XXVIII Encontro Nacional dos Programas de Pós-Graduação em Administração. Curitiba, 2004.

HANASHIRO, D. M. M.; QUEIROZ, R. C. O efeito da diversidade no desempenho dos times de trabalho: um trade-off entre homogeneidade e heterogeneidade? In: ENCONTRO NACIONAL DOS PROGRAMAS DE PÓS-GRADUAÇÃ̃O EM ADMINISTRAÇÃO (ENANPAD), 29, 2005, Brasília. Anais do XXIX Encontro Nacional dos Programas de PósGraduação em Administração. Brasília, 2005.

INSTITUTO BRASILEIRO DE GEOGRAFIA E ESTATÍSTICA (IBGE). Pesquisa Mensal de $\quad 2008 . \quad$ Emprego. $\quad$ Disponível em http://www.ibge.gov.br/home/presidencia/noticias/noticia_visualiza. Acesso em: 17 jul. 2008.

INSTITUTO BRASILEIRO DE QUALIDADE E PRODUTIVIDADE (IBQP). 2007. Disponível em http://www.ibqp.org.br/portal/home/index.php. Acesso em: 10 dez. 2008. 
IPAS BRASIL. Os 12 direitos da mulher. 2007. Disponível em: <http://www.ipas.org.br/ 12direitos.html>. Acesso em: 30 jul. 2008.

LALLEMENT, M. Os usos da comparação internacional na sociologia do gênero. In:

Mercado de Trabalho e Gênero. Rio de Janeiro: FGV, 2008. cap. 3.

MARUANI, M. Emprego, desemprego e precariedade: uma comparação européia. In:

Mercado de Trabalho e Gênero. Rio de Janeiro: FGV, 2008. cap. 2.

MINISTÉRIO DO TRABALHO E EMPREGO (TEM). 2007. Disponível em: http://www.mte.gov.br/rais/resultados_definitivos.asp. Acesso em: 02 jan. 2009.

MORGAN, G. A Criação da Realidade Social In: Imagens da Organização. Tradução de Cecília Whitakes Bergamini e Roberto Coda. São Paulo: Atlas, 1996. cap. 5.

MOURÃO, T. M. F. Participação das Mulheres no Mundo do Trabalho. In: Mulheres no Topo da Carreira. Brasília: Secretaria Especial de Políticas para as Mulheres, 2006. cap. 2.

PAZ, O. A Dialética da Solidão. In: O Labirinto da Solidão. Rio de Janeiro: Paz e Terra, 1976. cap. 2.

PICANÇO, F. S. Amélia e a mulher de verdade: representações dos papéis da mulher e do homem em relação ao trabalho e à vida familiar. In: . Gênero família e trabalho no Brasil. Rio de Janeiro: FGV, 2005. cap. 5.

PENNA. J.O.DE M. O Matriarcado, Gondwana e a Raça Morena. In: Em Berço Esplêndido. 2. ed. Rio de Janeiro: Instituto Liberal, 1999. cap. 4.

PRIORE, M. D. História das mulheres no Brasil. 3. ed. São Paulo: Contexto, 2000.

ROBBINS, S.P. Cultura Organizacional. In: Comportamento Organizacional. Tradução: Reynaldo Cavalheiro Marcondes. 11. ed. São Paulo: Pearson Prentice Hall, 2005. cap. 3.

RODDCK, A. Meu Jeito de Fazer Negócio. Tradução: Sérgio Gonçalves. 3. ed. Rio de Janeiro: Campus, 2002.

SALAS, C.; LEITE, M. Segregação setorial por gênero. In: Mercado de Trabalho e Gênero. Rio de Janeiro: FGV, 2008. cap. 5.

SECRETARIA ESPECIAL DE POLÍTICAS PARA AS MULHERES (SEPM). Relatório nacional brasileiro. 2007. Disponível em: http://www.presidencia.gov.br/estrutura_presidencia/sepm/publicacoes. Acesso em: 5 dez. 2008. 
SROUR, R. H. As Revoluções Tecnológicas, In:

Poder Cultura e Ética. O Desafio das Formas de Gestão. 13. ed. Rio de Janeiro: Elsevier, 2005. cap 4.

TABAK, F. Ciência, Tecnologia e Desenvolvimento Nacional. In: . O Laboratório de Pandora. Rio de Janeiro: Garamond, 2002. cap. 1.

UNESCO. Declaração Universal Sobre a Diversidade Cultural. 2002. Disponível em: http://www.unesco.org.br/publicacoes/copy_of_pdf/decuniv diversidadecultural.doc>. Acesso em: 20 jan. 2009.

VERGARA, S. C. Começando a definir a metodologia. In:

Projetos e relatórios de pesquisa em Administração. 2.ed. São Paulo: Atlas, 2007. cap. 4.

ZAULLI - FELLOWS, A. Diversidade e gênero na Câmara dos Deputados: um estudo sobre igualdade de oportunidade entre Mulheres e Homens. Dissertação (Mestrado em Gestão Social e Trabalho). Programa de Pós-Graduação em Administração - Universidade de Brasília, Brasília, 2006. 
ANEXO A - Questionário Aplicado à Amostra da Organização Estudada: Escala de

Percepção de Igualdade de Oportunidades entre Mulheres e Homens.

Prezado (a) Colega,

Esta pesquisa faz parte da monografia de final do curso de especialização em Gestão Judiciária que realizo na Universidade de Brasília, cujo tema é: INVESTIGAÇão SOBRE IGUALDADE DE OPORTUNIDADES ENTRE HOMENS E MULHERES.

Espero contar com a sua valiosa colaboração para responder este questionário. Para tanto, leia com atenção as considerações que seguem:

- As suas respostas serão analisadas de forma conjunta de modo a não permitir a sua identificação.

- Por favor, responda todas as questões, a qualidade dos resultados dependerá do seu empenho em responder com precisão e cuidado.

- Leia atentamente as questões e avalie, individualmente, o quanto cada uma delas descreve o que você pensa em relação à afirmativa.

É importante destacar que a escala adotada neste trabalho foi construída por Zauli-Fellows (2006) para avaliar a percepção sobre as oportunidades que a mulher tem de ocupar postos de comando, denominada "Escala de Percepção de Igualdade de Oportunidades entre Mulheres e Homens".

Agradeço antecipadamente a sua colaboração.

Maria Aparecida de Araújo Ramos

maria.ramos@stj.jus.br

Telefones: 3319-9630/9926-3595

Utilize a escala apresentada abaixo de cada item do questionário. Assinale apenas uma opção para cada item.

1. Na organização em que trabalho a diversidade de raça, gênero, idade, religião etc. é considerada uma vantagem para o desempenho organizacional.

\begin{tabular}{|c|c|c|c|c|}
\hline $\begin{array}{c}\text { Discordo } \\
\text { Totalmente }\end{array}$ & Discordo & $\begin{array}{c}\text { Não discordo } \\
\text { nem concordo }\end{array}$ & Concordo & $\begin{array}{c}\text { Concordo } \\
\text { Totalmente }\end{array}$ \\
\hline 1.( ) & 2.( ) & 3.( ) & 4.( ) & 5.( ) \\
\hline
\end{tabular}


2. As mulheres se consideram incapazes de ocupar cargos e funções comissionadas.

\begin{tabular}{|c|c|c|c|c|}
\hline $\begin{array}{c}\text { Discordo } \\
\text { Totalmente }\end{array}$ & Discordo & $\begin{array}{c}\text { Não discordo } \\
\text { nem concordo }\end{array}$ & Concordo & $\begin{array}{c}\text { Concordo } \\
\text { Totalmente }\end{array}$ \\
\hline 1.( ) & 2.( ) & 3.( ) & $4 .()$ & $5 .()$ \\
\hline
\end{tabular}

3. Na organização em que trabalho, o número de homens que ocupam cargos e funções comissionadas é maior por razões culturais.

\begin{tabular}{|c|c|c|c|c|}
\hline $\begin{array}{c}\text { Discordo } \\
\text { Totalmente }\end{array}$ & Discordo & $\begin{array}{c}\text { Não discordo } \\
\text { nem concordo }\end{array}$ & Concordo & $\begin{array}{c}\text { Concordo } \\
\text { Totalmente }\end{array}$ \\
\hline 1.( ) & 2.( ) & 3.( ) & 4.( ) & 5.( ) \\
\hline
\end{tabular}

4. As mulheres têm mais sensibilidade do que os homens para desempenhar tarefas que envolvem relacionamento interpessoal.

\begin{tabular}{|c|c|c|c|c|}
\hline $\begin{array}{c}\text { Discordo } \\
\text { Totalmente }\end{array}$ & Discordo & $\begin{array}{c}\text { Não discordo } \\
\text { nem concordo }\end{array}$ & Concordo & $\begin{array}{c}\text { Concordo } \\
\text { Totalmente }\end{array}$ \\
\hline 1.( ) & 2.( ) & 3.( ) & 4.( ) & 5.( ) \\
\hline
\end{tabular}

5. Na organização em que trabalho, ninguém deixou de ser escolhido para ocupar cargos e funções comissionadas por ser mulher.

\begin{tabular}{|c|c|c|c|c|}
\hline $\begin{array}{l}\text { Discordo } \\
\text { Totalmente }\end{array}$ & Discordo & $\begin{array}{c}\text { Não discordo } \\
\text { nem concordo }\end{array}$ & Concordo & $\begin{array}{c}\text { Concordo } \\
\text { Totalmente }\end{array}$ \\
\hline 1.( ) & 2.( ) & 3.( ) & 4.( ) & 5.( ) \\
\hline
\end{tabular}

6. O critério de promoção por mérito aumenta as oportunidades da mulher de ascensão na carreira.

\begin{tabular}{|c|c|c|c|c|}
\hline $\begin{array}{c}\text { Discordo } \\
\text { Totalmente }\end{array}$ & Discordo & $\begin{array}{c}\text { Não discordo } \\
\text { nem concordo }\end{array}$ & Concordo & $\begin{array}{c}\text { Concordo } \\
\text { Totalmente }\end{array}$ \\
\hline $1 .()$ & 2.( ) & 3.( ) & $4 .($ ) & $5 .($ ) \\
\hline
\end{tabular}

7. Na organização em que trabalho, é comum as/os servidoras/es acharem que os homens têm mais autoridade para gerenciar.

\begin{tabular}{|c|c|c|c|c|}
\hline $\begin{array}{c}\text { Discordo } \\
\text { Totalmente }\end{array}$ & Discordo & $\begin{array}{c}\text { Não discordo } \\
\text { nem concordo }\end{array}$ & Concordo & $\begin{array}{c}\text { Concordo } \\
\text { Totalmente }\end{array}$ \\
\hline 1.( ) & 2.( ) & 3.( ) & $4 .($ ) & $5 .($ ) \\
\hline
\end{tabular}

8. Mesmo que tenham competência, as mulheres não desejam ocupar cargos e funções comissionadas.

\begin{tabular}{|c|c|c|c|c|}
\hline $\begin{array}{c}\text { Discordo } \\
\text { Totalmente }\end{array}$ & Discordo & $\begin{array}{c}\text { Não discordo } \\
\text { nem concordo }\end{array}$ & Concordo & $\begin{array}{c}\text { Concordo } \\
\text { Totalmente }\end{array}$ \\
\hline 1.( ) & 2.( ) & 3.( ) & $4 .($ ) & 5.( ) \\
\hline
\end{tabular}


9. Na organização em que trabalho, por ter de lutar mais para atingir os objetivos desejados, as mulheres são mais comprometidas com o trabalho do que os homens.

\begin{tabular}{|c|c|c|c|c|}
\hline $\begin{array}{c}\text { Discordo } \\
\text { Totalmente }\end{array}$ & Discordo & $\begin{array}{c}\text { Não discordo } \\
\text { nem concordo }\end{array}$ & Concordo & $\begin{array}{c}\text { Concordo } \\
\text { Totalmente }\end{array}$ \\
\hline 1.( ) & 2.( ) & 3.( ) & 4.( ) & 5.( ) \\
\hline
\end{tabular}

10. As mulheres sentem que não são aceitas como chefes pelos homens.

\begin{tabular}{|c|c|c|c|c|}
\hline $\begin{array}{c}\text { Discordo } \\
\text { Totalmente }\end{array}$ & Discordo & $\begin{array}{c}\text { Não discordo } \\
\text { nem concordo }\end{array}$ & Concordo & $\begin{array}{c}\text { Concordo } \\
\text { Totalmente }\end{array}$ \\
\hline 1.( ) & 2.( ) & 3.( ) & 4.( ) & 5.( ) \\
\hline
\end{tabular}

11. A organização em que trabalho oferece oportunidades iguais de capacitação para homens e mulheres.

\begin{tabular}{|c|c|c|c|c|}
\hline $\begin{array}{c}\text { Discordo } \\
\text { Totalmente }\end{array}$ & Discordo & $\begin{array}{c}\text { Não discordo } \\
\text { nem concordo }\end{array}$ & Concordo & $\begin{array}{c}\text { Concordo } \\
\text { Totalmente }\end{array}$ \\
\hline 1.( ) & 2.( ) & 3.( ) & 4.( ) & 5.( ) \\
\hline
\end{tabular}

12. Os homens não gostam de ser chefiados por mulheres.

\begin{tabular}{|c|c|c|c|c|}
\hline $\begin{array}{c}\text { Discordo } \\
\text { Totalmente }\end{array}$ & Discordo & $\begin{array}{c}\text { Não discordo } \\
\text { nem concordo }\end{array}$ & Concordo & $\begin{array}{c}\text { Concordo } \\
\text { Totalmente }\end{array}$ \\
\hline 1.( ) & 2.( ) & 3.( ) & $4 .($ ) & $5 .($ ) \\
\hline
\end{tabular}

13. Na organização em que trabalho, o homem é sempre o escolhido nos processos de seleção interna para ocupar cargos e funções comissionadas.

\begin{tabular}{|c|c|c|c|c|}
\hline $\begin{array}{c}\text { Discordo } \\
\text { Totalmente }\end{array}$ & Discordo & $\begin{array}{c}\text { Não discordo } \\
\text { nem concordo }\end{array}$ & Concordo & $\begin{array}{c}\text { Concordo } \\
\text { Totalmente }\end{array}$ \\
\hline 1.( ) & 2.( ) & 3.( ) & $4 .($ ) & $5 .($ ) \\
\hline
\end{tabular}

14. As mulheres que recorrem ao uso da sedução têm mais oportunidades de ascensão na carreira.

\begin{tabular}{|c|c|c|c|c|}
\hline $\begin{array}{c}\text { Discordo } \\
\text { Totalmente }\end{array}$ & Discordo & $\begin{array}{c}\text { Não discordo } \\
\text { nem concordo }\end{array}$ & Concordo & $\begin{array}{c}\text { Concordo } \\
\text { Totalmente }\end{array}$ \\
\hline 1.( ) & 2.( ) & 3.( ) & 4.( ) & 5.( ) \\
\hline
\end{tabular}

15. Em organizações conservadoras, geralmente os cargos e funções comissionadas são ocupados por homens.

\begin{tabular}{|c|c|c|c|c|}
\hline $\begin{array}{c}\text { Discordo } \\
\text { Totalmente }\end{array}$ & Discordo & $\begin{array}{c}\text { Não discordo } \\
\text { nem concordo }\end{array}$ & Concordo & $\begin{array}{c}\text { Concordo } \\
\text { Totalmente }\end{array}$ \\
\hline 1.( ) & 2.( ) & 3.( ) & $4 .($ ) & $5 .($ ) \\
\hline
\end{tabular}


16. Na organização em que trabalho, geralmente os cargos e funções comissionadas são ocupados por homens.

\begin{tabular}{|c|c|c|c|c|}
\hline $\begin{array}{c}\text { Discordo } \\
\text { Totalmente }\end{array}$ & Discordo & $\begin{array}{c}\text { Não discordo } \\
\text { nem concordo }\end{array}$ & Concordo & $\begin{array}{c}\text { Concordo } \\
\text { Totalmente }\end{array}$ \\
\hline 1.( ) & 2.( ) & 3.( ) & 4.( ) & 5.( ) \\
\hline
\end{tabular}

17. Por achar que não serão escolhidas, as mulheres não se candidatam a processos de seleção interna para ocupar cargos e funções comissionadas.

\begin{tabular}{|c|c|c|c|c|}
\hline $\begin{array}{c}\text { Discordo } \\
\text { Totalmente }\end{array}$ & Discordo & $\begin{array}{c}\text { Não discordo } \\
\text { nem concordo }\end{array}$ & Concordo & $\begin{array}{c}\text { Concordo } \\
\text { Totalmente }\end{array}$ \\
\hline 1.( ) & 2.( ) & 3.( ) & 4.( ) & 5.( ) \\
\hline
\end{tabular}

18. Na organização em que trabalho, os homens têm mais oportunidades de ascensão na carreira por causa do preconceito existente contra as mulheres.

\begin{tabular}{|c|c|c|c|c|}
\hline $\begin{array}{c}\text { Discordo } \\
\text { Totalmente }\end{array}$ & Discordo & $\begin{array}{c}\text { Não discordo } \\
\text { nem concordo }\end{array}$ & Concordo & $\begin{array}{c}\text { Concordo } \\
\text { Totalmente }\end{array}$ \\
\hline 1.( ) & 2.( ) & 3.( ) & 4.( ) & 5.( ) \\
\hline
\end{tabular}

19. Minha organização nada pode fazer para que homens e mulheres tenham as mesmas oportunidades de ocupar cargos e funções comissionadas.

\begin{tabular}{|c|c|c|c|c|}
\hline $\begin{array}{c}\text { Discordo } \\
\text { Totalmente }\end{array}$ & Discordo & $\begin{array}{c}\text { Não discordo } \\
\text { nem concordo }\end{array}$ & Concordo & $\begin{array}{c}\text { Concordo } \\
\text { Totalmente }\end{array}$ \\
\hline 1.( ) & 2.( ) & 3.( ) & 4.( ) & 5.( ) \\
\hline
\end{tabular}

20. As mulheres têm medo de ocupar cargos e funções comissionadas.

\begin{tabular}{|c|c|c|c|c|}
\hline $\begin{array}{c}\text { Discordo } \\
\text { Totalmente }\end{array}$ & Discordo & $\begin{array}{c}\text { Não discordo } \\
\text { nem concordo }\end{array}$ & Concordo & $\begin{array}{c}\text { Concordo } \\
\text { Totalmente }\end{array}$ \\
\hline 1.( ) & 2.( ) & 3.( ) & $4 .($ ) & $5 .($ ) \\
\hline
\end{tabular}

21. Os homens têm dificuldade de lidar com as mulheres como iguais na atividade profissional.

\begin{tabular}{|c|c|c|c|c|}
\hline $\begin{array}{c}\text { Discordo } \\
\text { Totalmente }\end{array}$ & Discordo & $\begin{array}{c}\text { Não discordo } \\
\text { nem concordo }\end{array}$ & Concordo & $\begin{array}{c}\text { Concordo } \\
\text { Totalmente }\end{array}$ \\
\hline 1.( ) & 2.( ) & 3.( ) & 4.( ) & 5.( ) \\
\hline
\end{tabular}

22. Há carreiras tradicionalmente mais associadas a mulheres do que a homens, como as de enfermeira, secretária e professora.

\begin{tabular}{|c|c|c|c|c|}
\hline $\begin{array}{c}\text { Discordo } \\
\text { Totalmente }\end{array}$ & Discordo & $\begin{array}{c}\text { Não discordo } \\
\text { nem concordo }\end{array}$ & Concordo & $\begin{array}{c}\text { Concordo } \\
\text { Totalmente }\end{array}$ \\
\hline $1 .()$ & 2.( ) & 3.( ) & $4 .($ ) & $5 .($ ) \\
\hline
\end{tabular}


23. Se houver um cargo ou função comissionada vago, as oportunidades de ele ser ocupado por homens ou mulheres são as mesmas.

\begin{tabular}{|c|c|c|c|c|}
\hline $\begin{array}{c}\text { Discordo } \\
\text { Totalmente }\end{array}$ & Discordo & $\begin{array}{c}\text { Não discordo } \\
\text { nem concordo }\end{array}$ & Concordo & $\begin{array}{c}\text { Concordo } \\
\text { Totalmente }\end{array}$ \\
\hline 1.( ) & 2.( ) & 3.( ) & 4.( ) & 5.( ) \\
\hline
\end{tabular}

24. Por serem menos competitivas do que os homens, as mulheres não se candidatam a processos de seleção interna para ocupar cargos e funções comissionadas.

\begin{tabular}{|c|c|c|c|c|}
\hline $\begin{array}{c}\text { Discordo } \\
\text { Totalmente }\end{array}$ & Discordo & $\begin{array}{c}\text { Não discordo } \\
\text { nem concordo }\end{array}$ & Concordo & $\begin{array}{c}\text { Concordo } \\
\text { Totalmente }\end{array}$ \\
\hline 1.( ) & 2.( ) & 3.( ) & 4.( ) & 5.( ) \\
\hline
\end{tabular}

25. Na organização em que trabalho, até hoje os homens se sentem constrangidos quando são chefiados por uma mulher.

\begin{tabular}{|c|c|c|c|c|}
\hline $\begin{array}{c}\text { Discordo } \\
\text { Totalmente }\end{array}$ & Discordo & $\begin{array}{c}\text { Não discordo } \\
\text { nem concordo }\end{array}$ & Concordo & $\begin{array}{c}\text { Concordo } \\
\text { Totalmente }\end{array}$ \\
\hline 1.( ) & 2.( ) & 3.( ) & 4.( ) & 5.( ) \\
\hline
\end{tabular}

26. Na organização em que trabalho, sempre se faz avaliação do desempenho dos servidores.

\begin{tabular}{|c|c|c|c|c|}
\hline $\begin{array}{c}\text { Discordo } \\
\text { Totalmente }\end{array}$ & Discordo & $\begin{array}{c}\text { Não discordo } \\
\text { nem concordo }\end{array}$ & Concordo & $\begin{array}{c}\text { Concordo } \\
\text { Totalmente }\end{array}$ \\
\hline $1 .()$ & 2.( ) & 3.( ) & $4 .($ ) & $5 .($ ) \\
\hline
\end{tabular}

27. Na organização em que trabalho, as decisões são tomadas em equipe.

\begin{tabular}{|c|c|c|c|c|}
\hline $\begin{array}{c}\text { Discordo } \\
\text { Totalmente }\end{array}$ & Discordo & $\begin{array}{c}\text { Não discordo } \\
\text { nem concordo }\end{array}$ & Concordo & $\begin{array}{c}\text { Concordo } \\
\text { Totalmente }\end{array}$ \\
\hline 1.( ) & 2.( ) & 3.( ) & 4.( ) & 5.( ) \\
\hline
\end{tabular}

28. Na organização em que trabalho as mulheres são emocionalmente menos estáveis do que os homens.

\begin{tabular}{|c|c|c|c|c|}
\hline $\begin{array}{c}\text { Discordo } \\
\text { Totalmente }\end{array}$ & Discordo & $\begin{array}{c}\text { Não discordo } \\
\text { nem concordo }\end{array}$ & Concordo & $\begin{array}{c}\text { Concordo } \\
\text { Totalmente }\end{array}$ \\
\hline 1.( ) & 2.( ) & 3.( ) & 4.( ) & 5.( ) \\
\hline
\end{tabular}

29. Na organização em que trabalho, há retorno da avaliação feita dos servidores.

\begin{tabular}{|c|c|c|c|c|}
\hline $\begin{array}{c}\text { Discordo } \\
\text { Totalmente }\end{array}$ & Discordo & $\begin{array}{c}\text { Não discordo } \\
\text { nem concordo }\end{array}$ & Concordo & $\begin{array}{c}\text { Concordo } \\
\text { Totalmente }\end{array}$ \\
\hline 1.( ) & 2.( ) & 3.( ) & 4.( ) & 5.( ) \\
\hline
\end{tabular}


30. Na organização em que trabalho, investe-se muito no desenvolvimento profissional dos servidores.

\begin{tabular}{|c|c|c|c|c|}
\hline $\begin{array}{c}\text { Discordo } \\
\text { Totalmente }\end{array}$ & Discordo & $\begin{array}{c}\text { Não discordo } \\
\text { nem concordo }\end{array}$ & Concordo & $\begin{array}{c}\text { Concordo } \\
\text { Totalmente }\end{array}$ \\
\hline 1.( ) & 2.( ) & 3.( ) & 4.( ) & 5.( ) \\
\hline
\end{tabular}

31. Na organização em que trabalho, as/os funcionárias/os são treinadas/os para ter consciência da existência da diversidade de raça, de gênero, de idade, de religião etc.

\begin{tabular}{|c|c|c|c|c|}
\hline $\begin{array}{c}\text { Discordo } \\
\text { Totalmente }\end{array}$ & Discordo & $\begin{array}{c}\text { Não discordo } \\
\text { nem concordo }\end{array}$ & Concordo & $\begin{array}{c}\text { Concordo } \\
\text { Totalmente }\end{array}$ \\
\hline 1.( ) & 2.( ) & 3.( ) & 4.( ) & 5.( ) \\
\hline
\end{tabular}

32. Na organização em que trabalho, as mulheres são melhores líderes do que os homens.

\begin{tabular}{|c|c|c|c|c|}
\hline $\begin{array}{c}\text { Discordo } \\
\text { Totalmente }\end{array}$ & Discordo & $\begin{array}{c}\text { Não discordo } \\
\text { nem concordo }\end{array}$ & Concordo & $\begin{array}{c}\text { Concordo } \\
\text { Totalmente }\end{array}$ \\
\hline 1.( ) & 2.( ) & 3.( ) & 4.( ) & 5.( ) \\
\hline
\end{tabular}

33. Na organização em que trabalho, as mulheres que desejam ocupar cargos e funções comissionadas têm de enfrentar mais desafios do que os homens.

\begin{tabular}{|c|c|c|c|c|}
\hline $\begin{array}{c}\text { Discordo } \\
\text { Totalmente }\end{array}$ & Discordo & $\begin{array}{c}\text { Não discordo } \\
\text { nem concordo }\end{array}$ & Concordo & $\begin{array}{c}\text { Concordo } \\
\text { Totalmente }\end{array}$ \\
\hline $1 .()$ & 2.( ) & 3.( ) & $4 .($ ) & $5 .($ ) \\
\hline
\end{tabular}

34. Em geral, os homens atribuem o sucesso das mulheres à sensualidade feminina.

\begin{tabular}{|c|c|c|c|c|}
\hline $\begin{array}{c}\text { Discordo } \\
\text { Totalmente }\end{array}$ & Discordo & $\begin{array}{c}\text { Não discordo } \\
\text { nem concordo }\end{array}$ & Concordo & $\begin{array}{c}\text { Concordo } \\
\text { Totalmente }\end{array}$ \\
\hline 1.( ) & 2.( ) & 3.( ) & 4.( ) & 5.( ) \\
\hline
\end{tabular}

Para finalizar, com o objetivo de caracterizar os participantes da pesquisa, responda os seguintes itens:

\section{Sexo}
1.( ) Masculino
2.( ) Feminino

\section{Idade}
1.( ) Até 25 anos
4.( ) De 46 a 55 anos
2.( ) De 26 a 35 anos
5.( ) De 56 a 65 anos
3.( ) De 36 a 45 anos
6.( ) De 66 a 70 anos

\section{Estado Civil}
1.( ) Solteiro
4.( ) Separado
2.( ) Casado
5. ( ) Divorciado
3.( ) Viúvo
6.( ) Outro 
Quantos filhos você tem?
1.( ) Nenhum
4.( ) Três
2.( ) Um
5.( ) Quatro
3.( ) Dois
6.( ) Mais de quatro

\section{Escolaridade}

1.( ) $1^{\circ}$ grau

5.( ) Especialização

2.( ) $2^{\circ}$ grau

6.( ) Mestrado

3. ( ) Superior incompleto

7.( ) Doutorado

4.( ) Superior

Na organização em que trabalho, classifico-me como

1. ( ) Servidor ocupante de cargo efetivo de Analista

2.( ) Servidor ocupante de cargo efetivo de Técnico

3. ( ) Servidor Requisitado

4.( ) Servidor sem vínculo com a Administração Pública

5.( ) Servidor em Exercício Provisório

É ocupante de cargo em que área?
1.( ) Administrativa
2.( ) Judiciária

Há quanto tempo trabalho no Tribunal?
1.( ) Menos de 1 ano
5.( ) De 10 a 12 anos
2.( ) De 1 a 3 anos
6.( ) De 13 a 15 anos
3.( ) De 4 a 6 anos
7.( ) De 16 a 18 anos
4.( ) De 7 a 9 anos
8.( ) Mais de 18 anos

É ocupante de cargo em comissão ou função comissionada?
1.( ) Não
6. ( ) $\mathrm{CJ}-1$
2.( ) FC-2
7.( ) $\mathrm{CJ}-2$
3.( ) FC-4
8.( ) CJ-3
4.( ) FC-5
9.( ) CJ-4
5.( ) FC-6

Há quanto tempo ocupa cargo em comissão ou função comissionada?
1.( ) Não ocupo cargo/função comissionada
6.( ) De 10 a 12 anos
2.( ) Menos de 1 ano
7.( ) De 13 a 15 anos
3.( ) De 1 a 3 anos
8.( ) De 16 a 18 anos
4.( ) De 4 a 6 anos
9.( ) Mais de 18 anos
5.( ) De 7 a 9 anos

Obrigada por sua atenção e pelo tempo dedicado em responder a esta pesquisa! 
APÊNDICE A - Planilha de coleta de dados enviada aos principais órgãos do Poder Judiciário.

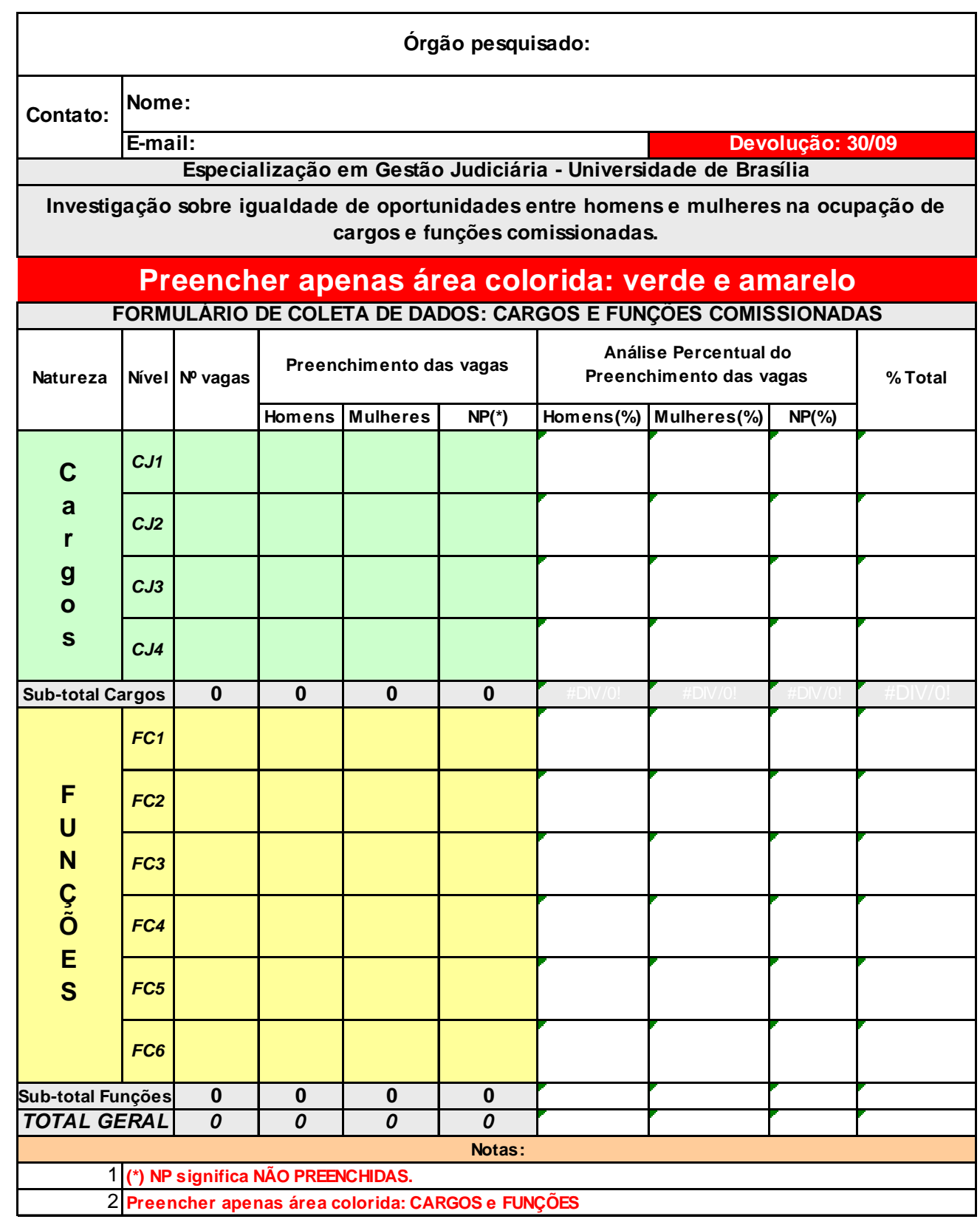


APÊNDICE A - Planilha de coleta de dados enviada aos principais órgãos do Poder Judiciário.(continuação).

\begin{tabular}{|c|c|c|c|c|c|}
\hline \multicolumn{6}{|c|}{ QUANTITATIVO DE HOMENS E MULHERES NO QUADRO DE PESSOAL } \\
\hline \multicolumn{3}{|c|}{$\begin{array}{l}\text { Quantitativo de Servidores no Quadro de Pessoal } \\
\text { (1) }\end{array}$} & \multicolumn{2}{|c|}{$\begin{array}{l}\text { Análise Percentual do } \\
\text { Preenchimento das vagas }\end{array}$} & \multirow[t]{2}{*}{$\%$ Total } \\
\hline Homens & Mulheres & TOTAL & Homens(\%) & Mulheres(\%) & \\
\hline & & 0 & & & \\
\hline \multicolumn{6}{|c|}{$\begin{array}{l}\text { (1) Deverão ser considerados todos os Servidores efetivos, requitados e sem vínculo } \\
\text { com o Órgão em questão }\end{array}$} \\
\hline
\end{tabular}

